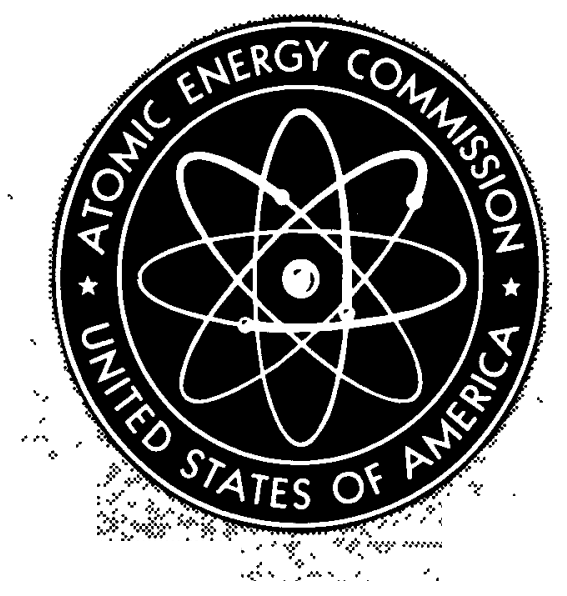

MND-P-2350

PHYSICS AND MATHEMATICS

\title{
SNAP I RADIOISOTOPE-FUELED TURBOELECTRIC POWER CONVERSION SYSTEM SUMMARY, JANUARY 1957 TO JUNE 1959 \\ By \\ Paul J. Dick
}

June 1960

Nuclear Division Martin Company

Baltimore, Maryland 


\section{DISCLAIMER}

This report was prepared as an account of work sponsored by an agency of the United States Government. Neither the United States Government nor any agency Thereof, nor any of their employees, makes any warranty, express or implied, or assumes any legal liability or responsibility for the accuracy, completeness, or usefulness of any information, apparatus, product, or process disclosed, or represents that its use would not infringe privately owned rights. Reference herein to any specific commercial product, process, or service by trade name, trademark, manufacturer, or otherwise does not necessarily constitute or imply its endorsement, recommendation, or favoring by the United States Government or any agency thereof. The views and opinions of authors expressed herein do not necessarily state or reflect those of the United States Government or any agency thereof. 


\section{DISCLAIMER}

Portions of this document may be illegible in electronic image products. Images are produced from the best available original document. 


\section{LEGAL NOTICE}

This report was prepared as an account of Government sponsored work. Neither the United States, nor the Commission, nor any person acting on behalf of the Commission:

A. Makes any warranty or representation, expressed or implied, with respect to the accuracy, completeness, or usefulness of the information contained in this report, or that the use of any information, apparatus, method, or process disclosed in this report may not infringe privately owned rights; or

B. Assumes any liabllities with respect to the use of, or for damages resulting from the use of any information, apparatus, method, or process disclosed in this report.

As used in the above, "person acting on behalf of the Commission" includes any employee or contractor of the Commission, or employee of such contractor, to the extent that such employee or contractor of the Commission, or employee of such contractor prepares, disseminates, or provides access to, any information pursuant to his employment or contract with the Commission, or his employment with such contractor.

This report has been reproduced directly from the best available copy.

Printed in USA. Price $\$ 1.50$. Available from the Office of Technical Services, Department of Commerce, Washington 25, D. C. 


\author{
MND-P-2350 \\ SNAP I \\ RADIOISOTOPE-FUELED \\ TURBOELECTRIC POWER CONVERSION \\ SYSTEM SUMMARY
}

January 1957 to June 1959

June 1960

Prepared by: Paul J. Dick

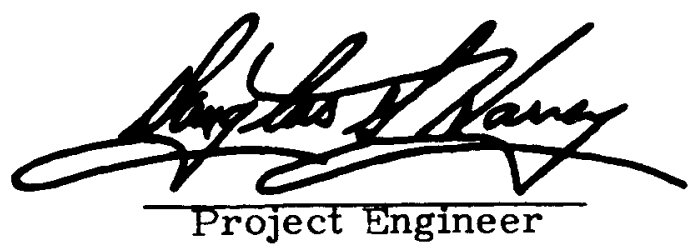

This report is prepared under Contract AT(30-3)-217 with the United States Atomic Energy Commission

Nuclear Division

Martin Company

Baltimore, Maryland 
page blank 


\section{FOREWORD}

This report has been prepared by The Martin Company as partial fulfillment of Task I for Fiscal Year 1960 to summarize the results of the SNAP I, radioisotope-fueled, turboelectric power conversion system. The SNAP I program was conducted by The Martin Company under Contract AT(30-3)-217 from the U。S Atomic Energy Commission。 Thompson Ramo Wooldridge (TRW) was the major subcontractor in developing the turboelectric conversion system.

The Martin Company was responsible for:

(1) The development of a superheated mercury loop heat exchanger utilizing a radioisotope heat source for space applications.

(2) The mechanical and radiological aspects of the power conversion system integration into a space satellite vehicle.

Thompson Ramo Wooldridge was responsible for the development of a space-oriented, Rankine-cycle, turboelectric system to convert the thermal energy of superheated mercury into electrical power. 
page blank 
Foreword .................. $v$

Contents.................. vii

Summary. . . . . . . . . . . . . . ix

I. Introduction . . . . . . . . . . . . . 1

II. Power Conversion System Development (Ref. 1). . . . 3

A. Objectives and Results ............ 3

B. Future Growth Potential ............ 3

III. Mercury Boiler Development (Ref. 2) . . . . . . 9

A. Objectives and Results ............. 9

B. Future Growth Potential . . . . . . . . . 13

IV. Dynamic Mercury Loop Tests of Selected Materials (Ref. 3) ................... 15

A. Objectives and Results ............ 15

B. Future Growth Potential . . . . . . . . . 17

V. Power Conversion System Turbine Development (Ref.4) ..................... 19

A. Objectives and Results ............. 19

B. Future Growth Potential . . . . . . . . . 23

VI. Power Conversion System Alternator Development (Ref. 5) .................... 25 


\section{CONTENTS (continued)}

A. Objectives and Results . . . . . . . . . . 25

B. Future Growth Potential. . . . . . . . . . 31

VII. Power Conversion System Pump Development

(Ref.6).................. . . 33

A. Objectives and Results ............ 33

VIII. Power Conversion System Bearing Development

(Ref. 7)................ . . . 39

A. Objectives and Results. . . . . . . . . . 39

B. Future Growth Potential. ............. 41

IX. Power Conversion System Control Development

(Ref. 8)..................... 43

A. Objectives and Results ............. 43

X. Power Conversion System Condenser-Radiator

Development (Ref.9) . . . . . . . . . . 47

A. Objectives and Results. . . . . . . . . . . 47

XI. Power Conversion System Materials Development

(Ref. 10).................. 49

A. Objectives and Results . . . . . . . . . . 49

B. Future Growth Potential. . . . . . . . . 50

XII. Conclusions . . . . . . . . . . . . . . 51

XIII. Bibliography . . . . . . . . . . . . . . 53

XIV. References.................. 55 
SUMMARY

The SNAP I development program was initiated in January 1957 to develop a 500 -watt, turboelectric power conversion system for space applications. Superheated mercury vapor was used as the heat conversion working fluid. The conversion system was to obtain thermal energy from the decay of a radioisotope fuel such as Cerium-144.

In this report, each of the major components and systems, is summarized with respect to initial design objectives, development progress to the point of program termination, results obtained from tests and, where indicated, future growth potential. Reference is made to 10 other reports which describe, in detail, the major components of this power generating system. Also included is a bibliography of Martin documented reports that are related to the power conversion system design criteria or system integration into a flight vehicle. 


\section{I。 INTRODUCTION}

Upon expiration of the 2-1/2-year SNAP I development program under Martin Company contract to the U。S.Atomic Energy Commission, it was considered appropriate and necessary to preserve this valuable experience in the form of technical reports. Task I for Fiscal Year 1960 was therefore established to document the SNAP I work that was not continued in the SNAP IA radioisotope-powered, thermoelectric generator development program.

This report will:

(1) Summarize, objectively, the detailed information presented in 10 related technical reports that were prepared by Thompson Ramo Wooldridge and The Martin Company.

(2) Serve as a concise reference for a literature search should future investigations into turboelectric power conversion systems utilizing mercury as the working fluid be required.

Subsequent sections will consider highlights of the following reports:

(1) "SNAP I Power Conversion System Development," ER-4050, TRW, 20 June 1960。

(2) "SNAP I Mercury Boiler Development," MND-P-2309, The Martin Company, June 1960。

(3) "SNAP I Dynamic Mercury Loop Tests of Selected Materials," MND-P-2128, The Martin Company, March 1960.

(4) "SNAP I Power Conversion System Turbine Development," ER-4051, TRW, 20 June 1960。

(5) "SNAP I Power Conversion System Alternator Development," ER-4052,TRW, 20 June 1960。

(6) "SNAP I Conversion System Pump Development," ER-4053, TRW, 20 June 1960 .

(7) "SNAP I Power Conversion System Bearing Development," ER-4054, TRW, 20 June 1960 .

(8) "SNAP I Power Conversion System Control Development," ER-4055, TRW, 20 June 1960。 
(9) "SNAP I Power Conversion System Condenser-Radiator Development," ER-4056, TRW, 20 June 1960。

(10) "SNAP I Power Conversion System Materials Development," ER-4057, TRW, 20 June 1960。 


\section{POWER CONVERSION SYSTEM DEVELOPMENT (REF. 1)}

SNAP I was originally designed to provide 500 watts of electrical power for an earth orbiting satellite and to have a useful life of 60 days. Figure 1 illustrates a typical installation of the radioisotope-fueled, turboelectric power conversion system in a satellite vehicle. The basic design of this system is shown by block diagram in Fig. 2. Thermal energy is obtained from two parallel flow connected, radioisotope-powered mercury boilers. Superheated mercury vapor then passes through a threestage turbine, to which a permanent magnet, brushless generator and a jet-boosted centrifugal pump are directly connected on a common shaft. The shaft is supported by mercury-lubricated hydrosphere bearings. Mercury, as it discharges from the turbine, passes through a condenser and the centrifugal pump and then returns to the mercury boilers. Unused cycle fluid heat is discharged to space in the combined condenserradiator. Excess heat of radioisotope decay is radiated to space through an integral sliding shutter in each of the radioisotope-powered mercury boilers.

\section{A. OBJECTIVES AND RESULTS}

A comparison of original turbomachinery performance objectives with experimental results is shown in Table 1. As can be observed from these data, component performance objectives were exceeded for the turbine and pump. Alternator efficiency was within $4 \%$ of the design objective. Power consumption was exceeded by 96 watts, while the turbomachinery package was 12 pounds below the target weight. Power output was within 30 watts of the 500 -watt objective.

A particularly notable achievement was the complete power conversion system endurance run of 104 days. The system was then voluntarily shut down for a detailed component inspection. The original design objective of 60 days was therefore exceeded by 44 days.

\section{B. FUTURE GROWTH POTENTIAL}

Areas where system improvements can be made are primarily in compactness and operational lifetime. Several studies have been performed which indicate that a modular design would greatly increase compactness and simplicity. In this concept, the turbomachinery package would be attached directly to the radioisotope heat source, and the entire system would be surrounded by a shell which would act as the condenserradiator and also as the container for the mercury biological shield. 


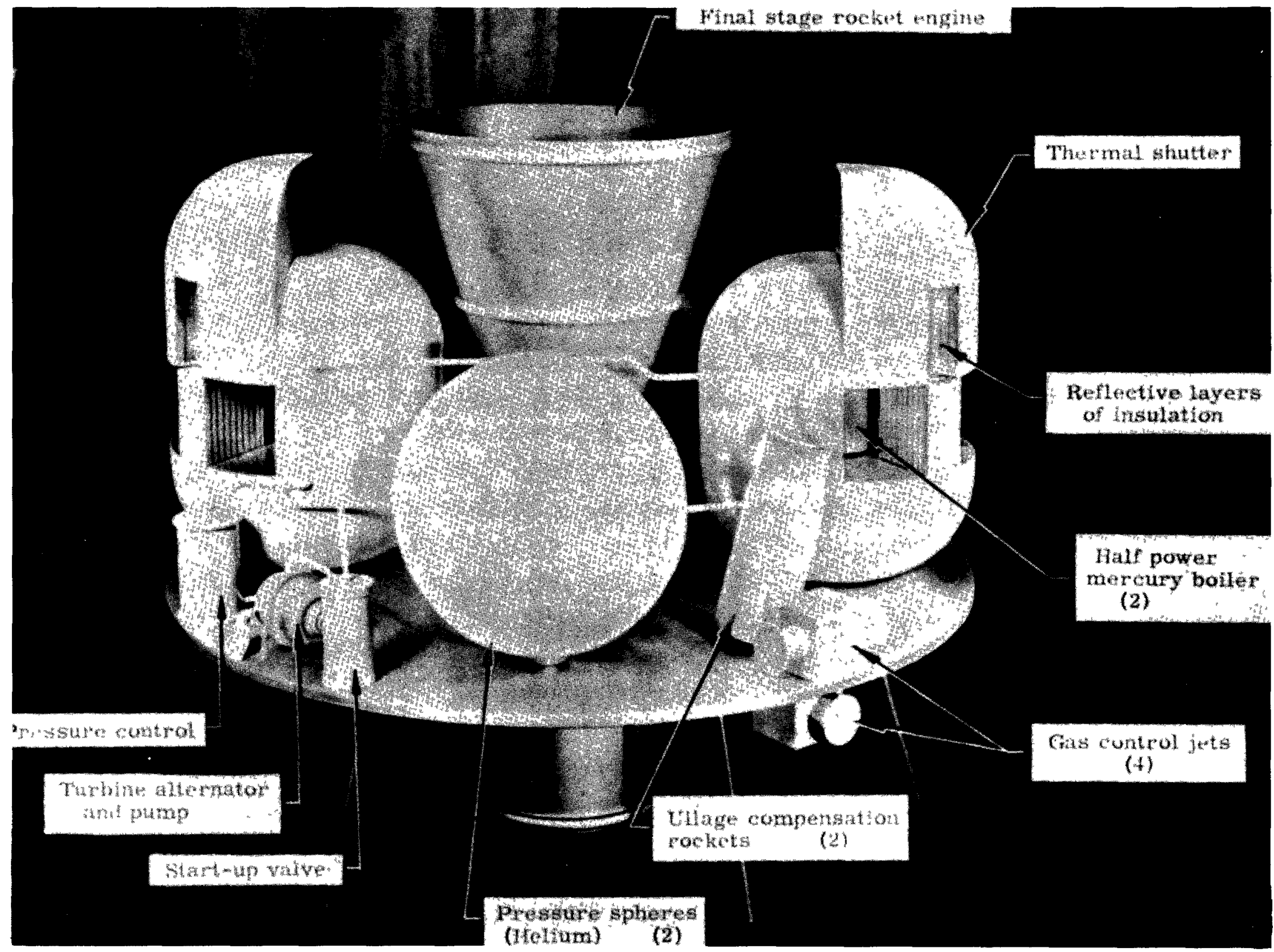

Fig. 1. SNAP I Space Mockup 


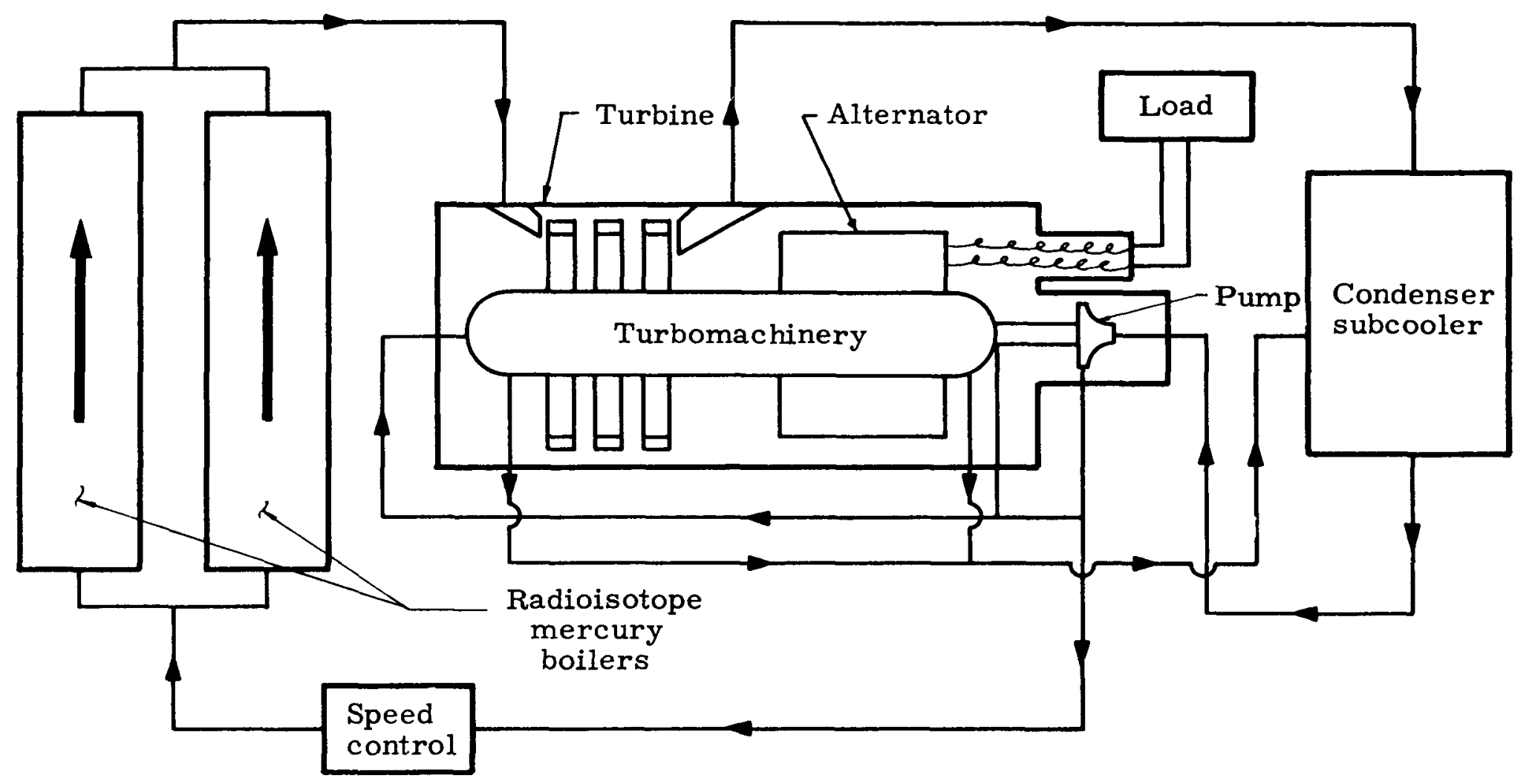

Fig. 2. Radioisotope-Fueled Power Conversion System 
TABLE 1

Turbomachinery Performance

Component

Turbine

Overall efficiency $(\%)$

Power (watts)

Bearings

Power consumption

(watts)

Original Design

Objective

605

40
Experimentally

Achieved

Performance

Pump

Overall efficiency $(\%)$

25

42.3

682

Power consumption

(watts)

110

Control

Power (watts)

25

15

Alternator

Overall efficiency (\%)

85

82.5

Turbomachinery package

Overall efficiency (\%)

Weight (lb)

10

9.4

Life (days)

25

13

60

104*

Overall power output

(watts)

500

470

* At time of voluntary shutdown。 
SNAP I system startup before launch imposes several complications and penalties. Studies to determine the feasibility of system startup after reaching orbit were conducted, and the attractiveness of this approach was demonstrated. In one arrangement, an electrically driven pump would be totally enclosed with mercury-lubricated bearings. The separate pump concept has several poteritial advantages in addition to its orbital start capabilities:

(1) The pump speed is no longer fixed by the turbine-alternator speed.

(2) A speed more advantageous for good pump operation may be chosen.

(3) Power output of the system can be controlled through control of the pump speed.

In the case of a radioisotope heat source, the boiler flow rate would be adjusted to match the heat source output at all times, eliminating the requirement for a variable heat rejection from the boiler. Power output over and above the requirements of the mission would be absorbed on a parasitic electrical load. 
page blank 


\section{MERCURY BOILER DEVELOPMENT (REF. 2)}

The mercury boiler development program was undertaken to utilize the heat of radioisotope decay by boiling and superheating mercury to the vapor state for use with the turboelectric power conversion system.

During the development period of January 1957 through April 1959, several changes were made to the conceptual designs and functional prototypes. The final half-power boiler configuration which was tested and integrated into the power conversion system is shown in Fig. 3. A molybdenum core contains bayonet-type electrical heaters to simulate the heat of radioisotope decay. The core was wrapped with 24 feet of mercury-carrying tubing in the form of a helical coil. A turbulence promoter, 19 feet long, was installed within the 3/8-inch OD stainless steel tubing. A stainless steel envelope housed the heat source, heat exchanger coil and molten lead which was used as an efficient thermal bond medium. Components of the fabricated half-power boiler are shown in Fig. 4.

Design development studies were conducted to establish ground handling procedures and an excess heat dump system for the radioisotopefueled mercury boiler. In addition, various analytical investigations were conducted on the boiler to obtain a complete thermal history of the unit. The principal areas of study were:

(1) Steady-state thermal analysis of the molybdenum fuel core.

(2) Transient analysis of the fuel core.

(3) Combined axial and radial core temperature distribution and mercury heat transfer.

(4) Boiler and boiler loop heat loss.

\section{A. OBJECTIVES AND RESULTS}

The final design of the half-power boiler, two of which were to be used in the power conversion system, was to have the following performance objectives:

Mercury vapor flow

Fluid discharge pressure Fluid discharge temperature Boiler internal pressure drop
$0.935 \mathrm{lb} / \mathrm{min}$

210 psia $1300^{\circ} \mathrm{F}$ $15 \mathrm{psi}$ 

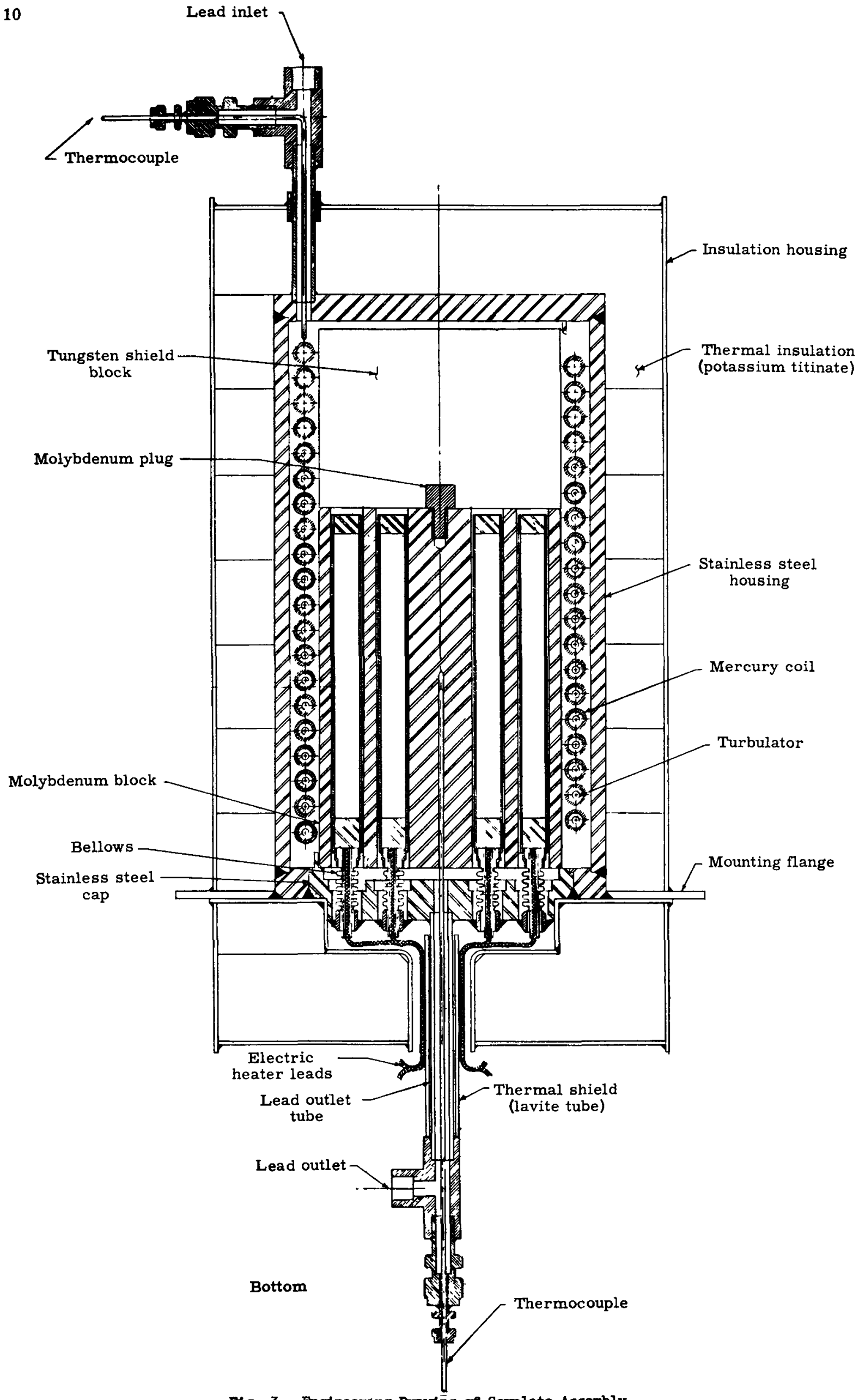

F18. 3. Fnglneering Draring of Complete Assembly 

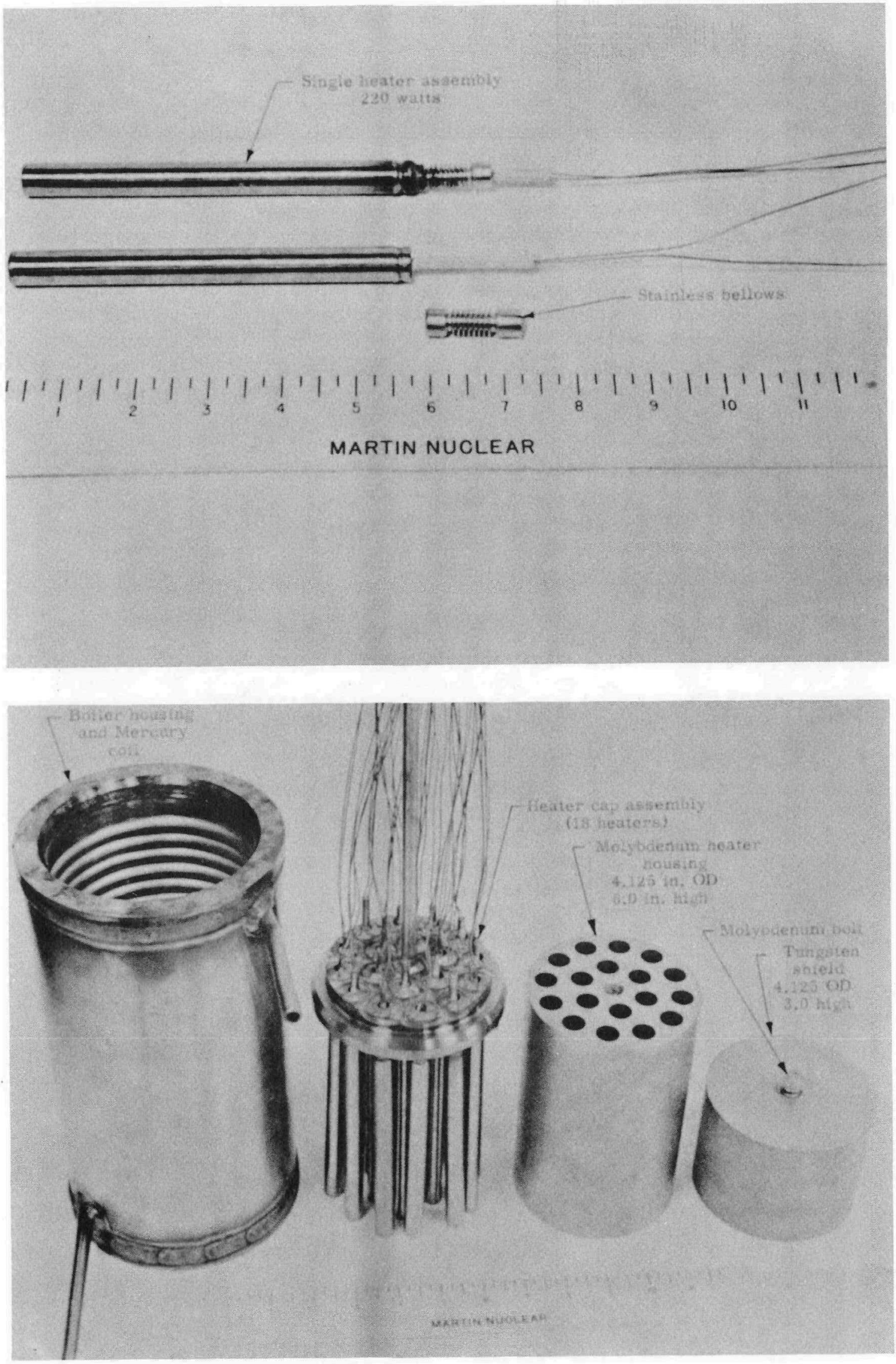

Fig. 4. Single Heater and Boiler Components 
A total of five boilers were fabricated which could produce superheated mercury vapor at the design conditions of flow, discharge pressure and discharge temperature. The initial boiler of this series exceeded the design internal pressure drop by 35 psi, however. Pressure drop requirements were met for the remaining four units by increasing the turbulence promoter pitch from $1 / 4$ to 1 inch and by increasing the boiler coil length from 12.5 to 19 feet in the case of the second boiler and to 24 feet for the third, fourth and fifth boilers.

Table 2 lists the important test boilers and their ultimate disposition.

TABLE 2

Summary of Mercury Boilers and Disposition

Coil Pressure

Drop Thermal

Insulation

Full-power

(psi)

125

Super X

Final

boiler

50

Preliminary

boiler

13 reflective shields

Prototype 1

Prototype 2

50

Potassium

titanate

Prototype 3

12

Potassium titanate

Disposition

Operated to destruction

Prototype 4

15

Potassium titanate

Prototype 5

Potassium titanate

Operated to destruction

Prototype $5 \mathrm{~A}$

Potassium titanate

Operated to destruction

Potassium titanate

Operated in dual boiler and thermal shock tests

Delivered to TRW

Prototype 6A 15

Potassium

Delivered to TRW

Isotope boiler

15

Potassium

BSP-1 titanate

Delivered to TRW

Cancelled and modified for heat transfer tests

Cancelled during fabrication

Cancelled during fabrication 


\section{B. FUTURE GROWTH POTENTIAL}

Two half-power mercury boilers were used in the final design to provide a conversion system output of 500 watts electrical. Half - power boilers were used because of flight vehicle weight symmetry and clearance considerations. The original development of a full-power boiler exhibited a high internal pressure drop of 125 psi. Later design improvements associated with the half-power boilers would have produced acceptable performance similar to that of the full-power configuration. In addition, potential flow instability of the parallel flow, half-power design would be eliminated with a full-power boiler.

The difficulties in delivering high temperature mercury vapor to the power conversion turbine nozzle without mercury condensation requires further development. To illustrate, data obtained from a Mercury Mollier Diagram are shown in Table 3 .

TABLE 3

Mercury Mollier Diagram Data

Pressure
(psia)

210

210

210

210

210
Temperature

$\left({ }^{\circ} \mathrm{F}\right)$

1300

1200

1100

1050

1025
Enthalpy

(Btu/lb)

163.0

160.5

158.0

156.7

156.1

The total enthalpy change from $1300^{\circ} \mathrm{F}$ vapor to the saturation vapor line at $1025^{\circ} \mathrm{F}$ is only $6.9 \mathrm{Btu} / \mathrm{lb}$. Each half-power boiler, at design conditions, delivered $0.935 \mathrm{lb} / \mathrm{min}$ and therefore would require a loss of only $6.45 \mathrm{Btu} / \mathrm{min}$ to reach saturation. Because of this, all exit vapor lines were wrapped with electric heaters to maintain high wall temperatures and prevent excessive heat losses. In spite of these precautions, mercury vapor temperatures dropped $200^{\circ} \mathrm{F}$ and lower at the simulated turbine nozzle package. Heat losses in the boiler exit lines are therefore a decided problem that will require further development. 
page blank 
IV. DYNAMIC MERCURY LOOP TESTS OF SELECTED MATERIALS

(REF, 3)

Successful operation of the SNAP I mercury vapor, turbine-driven power conversion system was dependent upon selecting boiler materials which would withstand prolonged exposure to boiling mercury. A total of six dynamic boiling mercury loops were therefore tested to aid in materials selection. The loops were Croloy-5 $\mathrm{Si}$, Croloy-5 Ti, Carpenter $20 \mathrm{Cb}$, Types 347 and 446 stainless steel and a Type 347 stainless steel-clad niobium boiler coil inserted into a Type 347 stainless steel loop. Type 316 stainless steel tubing was also used in the boiler outlet and condenser tubing lines associated with a mercury boiler test rig.

The selection of test materials was based mainly on the literature and the reportedly good results of certain materials in mercury cycle power plants. Although magnesium and titanium inhibitors are normally used in these systems, it was decided that none would be used in the loop tests because the normal product of reaction, a very fine powder of iron and magnesium oxides, could not be easily removed. The elimination of corrosion inhibitors, combined with the much higher operating temperature of the SNAP I system, excluded the materials normally used in mercury cycle power plants from active consideration.

\section{A. OBJECTIVES AND RESULTS}

The dynamic loops were designed to test the operating conditions of the actual power conversion system, i.e., boil the mercury at $1025^{\circ}$ to $1050^{\circ} \mathrm{F}$, superheat the vapor to $1350^{\circ} \mathrm{F}$ and condense at $1000^{\circ}$ and $350^{\circ} \mathrm{F}$ in three each of the six loops, respectively. Sixty days of satisfactory operation was the minimum requirement. A typical schematic for the dynamic loop tests is shown in Fig。 5.

Operation of the Croloy-5 Si loop was discontinued after about 86 hours because the heaters burned out. Extensive general corrosion that penetrated as much as 3.5 mils occurred during this time. The boiler outlet leg of the Croloy-5 Ti loop ruptured after 166 hours of operation. Again, extensive general corrosion occurred with up to 5 mils of penetration. The Carpenter $20 \mathrm{Cb}$ loop was never operated at design conditions: it failed after a short time when arcing from the heater to the coil burned through the tubing. The Type 347 stainless steel loop failed after 326 hours when the outlet leg of the boiler coil ruptured. Extensive depletion of nickel with penetrations of up to 20 mils was found in the condenser. 


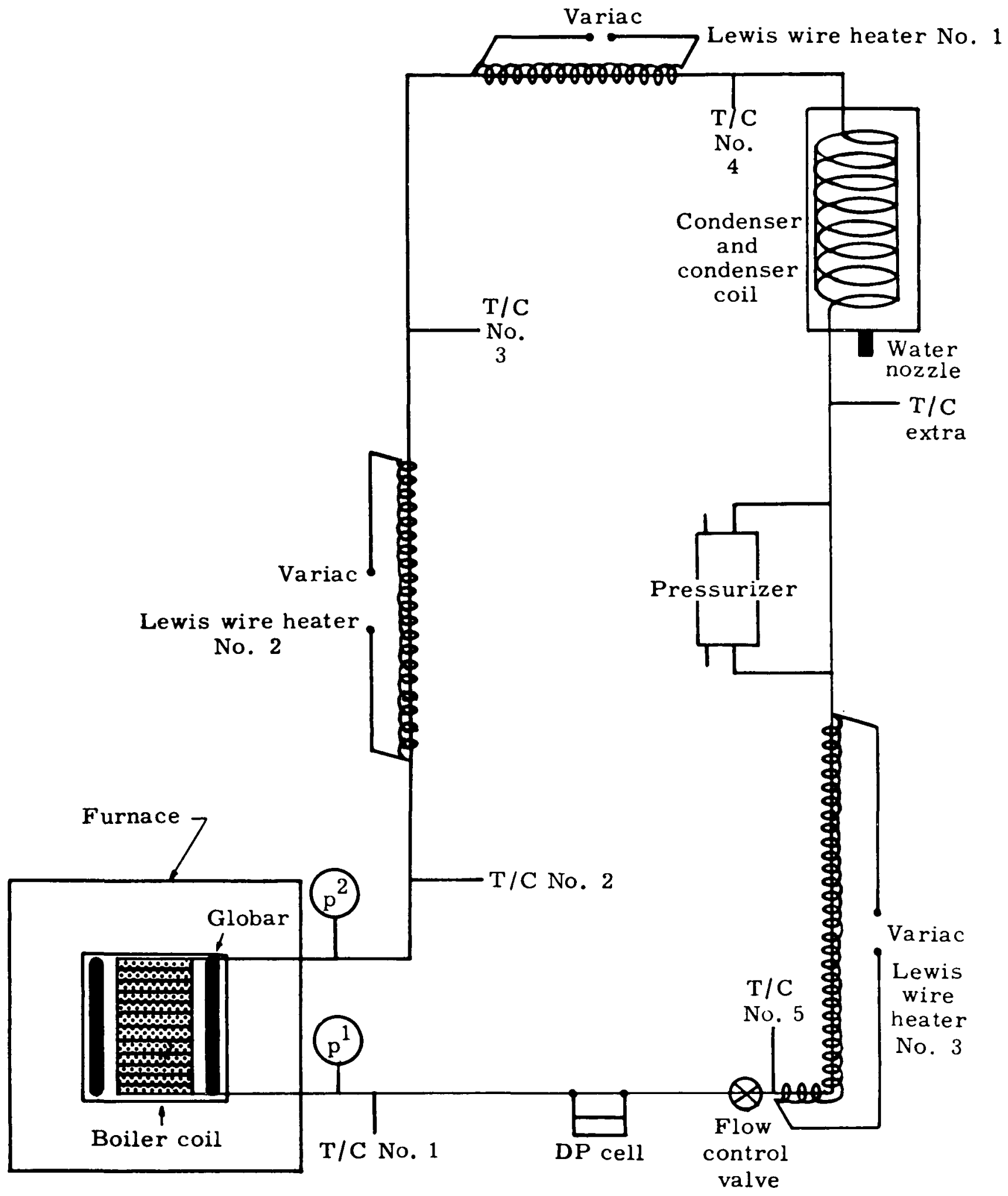

Fig. 5. Schematic of Design for Types 347 and 446 Stainless Steel Loops 
The Type 446 stainless steel loop did not fail although its operation was discontinued after 141 hours because of multiple leaks. Numerous transgranular cracks were found in the boiler coil, the origin of these cracks being problematical, but the remainder of this loop was apparently unaffected. The niobium coil ruptured after 50 hours of operation, the failure probably being caused by atmospheric oxygen contacting the niobium when the Type 347 stainless steel cladding failed。

Successful operating experiences involving two-phase mercury flow and totaling more than 500 hours were obtained using Type 316 stainless steel tubing. Operating conditions for the mercury working fluid at the inlet of this tubing were $200 \mathrm{psia}$ and $1100^{\circ}$ to $1350^{\circ} \mathrm{F}$ 。

\section{B. FUTURE GROWTH POTENTIAL}

It was considered that the dynamic loop design, after considerable modification and operating experience, was sound and had proved satisfactory on at least four test runs. Unfortunate material failures and plant power outages were the major contributors to loop shutdown。A few changes in the design are recommended to permit smoother operation, $i_{0}$ e., weld all connections in the loop cold leg as well as in the hot leg, redesign the pressurizer to permit direct mercury charging and provide a positive maintenance of an argon gas blanket over the boiler coil. It is also very important to ensure that all materials to be tested are properly fabricated and sound, $i_{\circ} e_{\circ}$, the sigma phase in the Type 446 and the severe cold work in the Type 347 stainless steels should be avoided。 
page blank 


\section{V。 POWER CONVERSION SYSTEM TURBINE DEVELOPMENT}

(REF。4)

The SNAP I mercury vapor turbine development program included the analysis, design, fabrication and testing of several turbine types to determine feasibility, obtain experimental results and select a turbine capable of meeting the design specifications. Preliminary analytical and experimental investigations of the regenerative-type turbines (drag and vortex) indicated that these turbines were relatively low efficiency machines and extensive development beyond the present state of the art would be required to obtain the design efficiency of $40 \%$. Final analytical and experimental development was conducted on the axial flow impulse turbine due to the advanced state of the art of this type.

The final SNAP I turbine consisted of a three-stage, axial flow, impulse, mercury vapor turbine with the first two stages having partial admission and the third stage having full admission. Basic considerations in the turbine design were reliability, weight, size, efficiency, performance, erosion, external leakage, life and system integration.

\section{A, OBJECTIVES AND RESULTS}

The SNAP I Rankine-cycle power conversion system required a turbine design capable of utilizing the high pressure and high temperature mercury vapor at the turbine inlet. The high pressure superheated vapor was converted into mechanical rotating energy by expansion through the turbine. Useful electrical power was obtained from an alternator coupled to the turbine shaft.

The turbine for the SNAP I power conversion system was required to supply sufficient power to drive the alternator and a pump at the design speed and to overcome the parasitic losses of the unit. The turbine was required to accomplish this task with no external leakage and at a minimum weight. Actually, the specific design objectives of the turbine varied as the SNAP I power output requirements were increased and the system design was formulated. This overall system development resulted in the final turbine design requirements listed in Table 4. 


\section{TABLE 4}

SNAP I Turbine Design Specifications

Fluid

Shaft speed (rpm)

Inlet total pressure (psia)

Inlet total temperature $\left({ }^{\circ} \mathrm{F}\right)$

Exhaust pressure (psia)

Weight flow (lb/sec)

Power output (watts)

Efficiency $(\%)$

Life (days)
Hg vapor

40,000

210

1300

2.06

0.0311

654

40.0

60

Plots of turbine aerodynamic power and efficiency versus speed in rpm can be found in Figs. 6 and 7. These plots show the range of values and an arithmetic average of points at each speed. It can be seen that the peak power and efficiency occurred in the vicinity of $40,000 \mathrm{rpm}$ at average values of 682 wacts of aerodynamic power and $42.3 \%$ aerodynamic total-to-static turbine efficiency。

Table 5 is a comparison of experimental and predicted turbine performance at $40,00 \mathrm{rpm}$ for Prototype Test Package 1. The experimental results are expressed in terms of aerodynamic power and efficiency, while the predicted values were for the shaft power from the turbine. To make a valid comparison, the viscous drags within the turbine should be added to the design prediction. This value was estimated as 27 watts.

Experimental results verified that the SNAP I axial flow, mercury vapor turbine successfully attained final design specifications. The overall turbine efficiency at the design point was $42.3 \%$ with a corresponding shaft output power of 682 watts.

Analytical and empirical axial flow turbine design procedures were evolved and verified by experimental air and mercury vapor testing for low power output, high pressure ratio, high speed mercury vapor turbines。 Digital computer programs were also utilized in the analysis, design and experimental evaluation of the SNAP I axial flow turbine.

Integration of the axial flow turbine into the turbomachinery package of the prototype power conversion system was successfully completed.

The SNAP I turboalternator package and system exceeded the life requirement of 60 days of operation during endurance testing. 


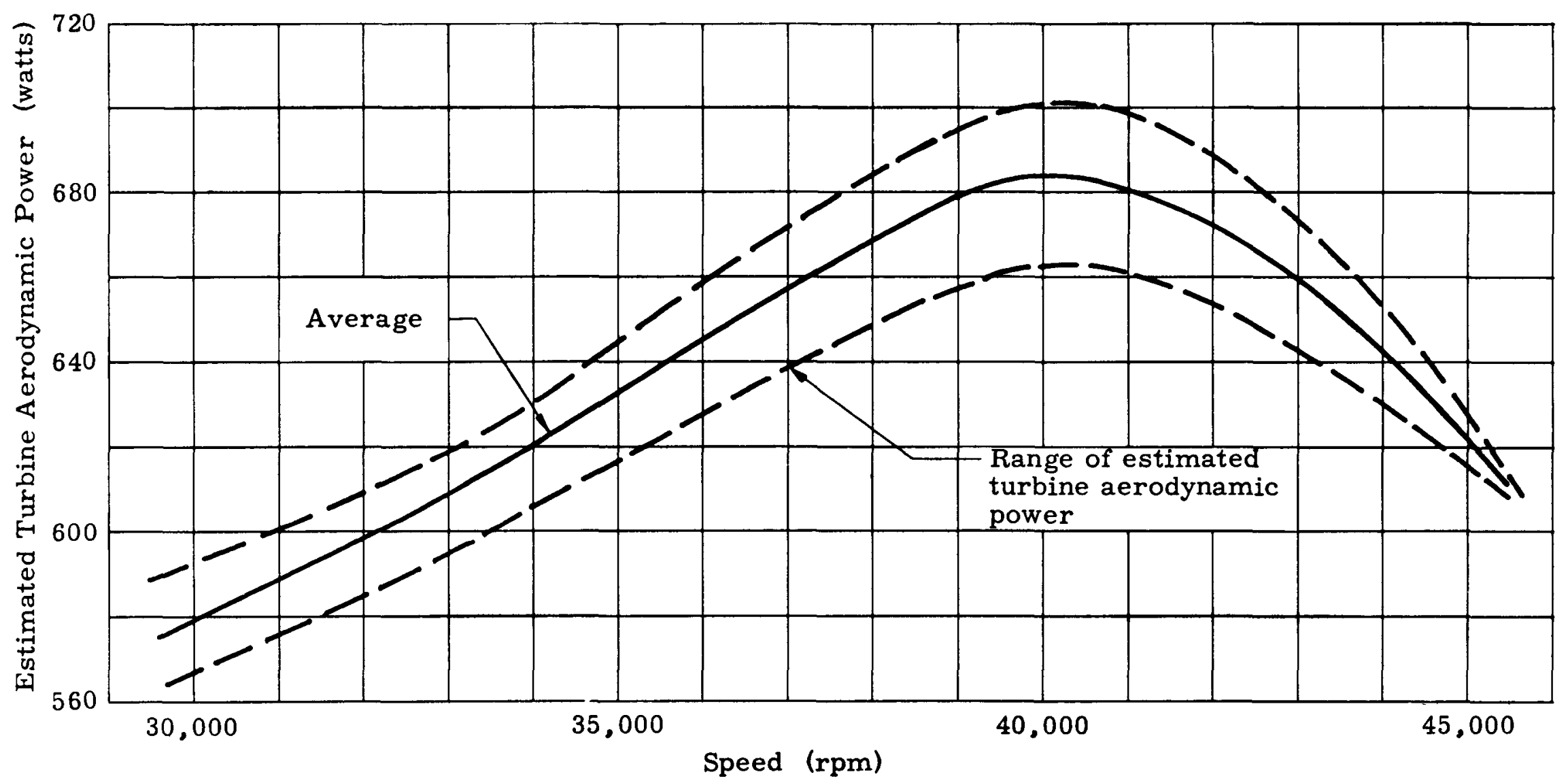

Fig. 6. Estimated Turbine Aerodynamic Power Versus Rotational Speed 


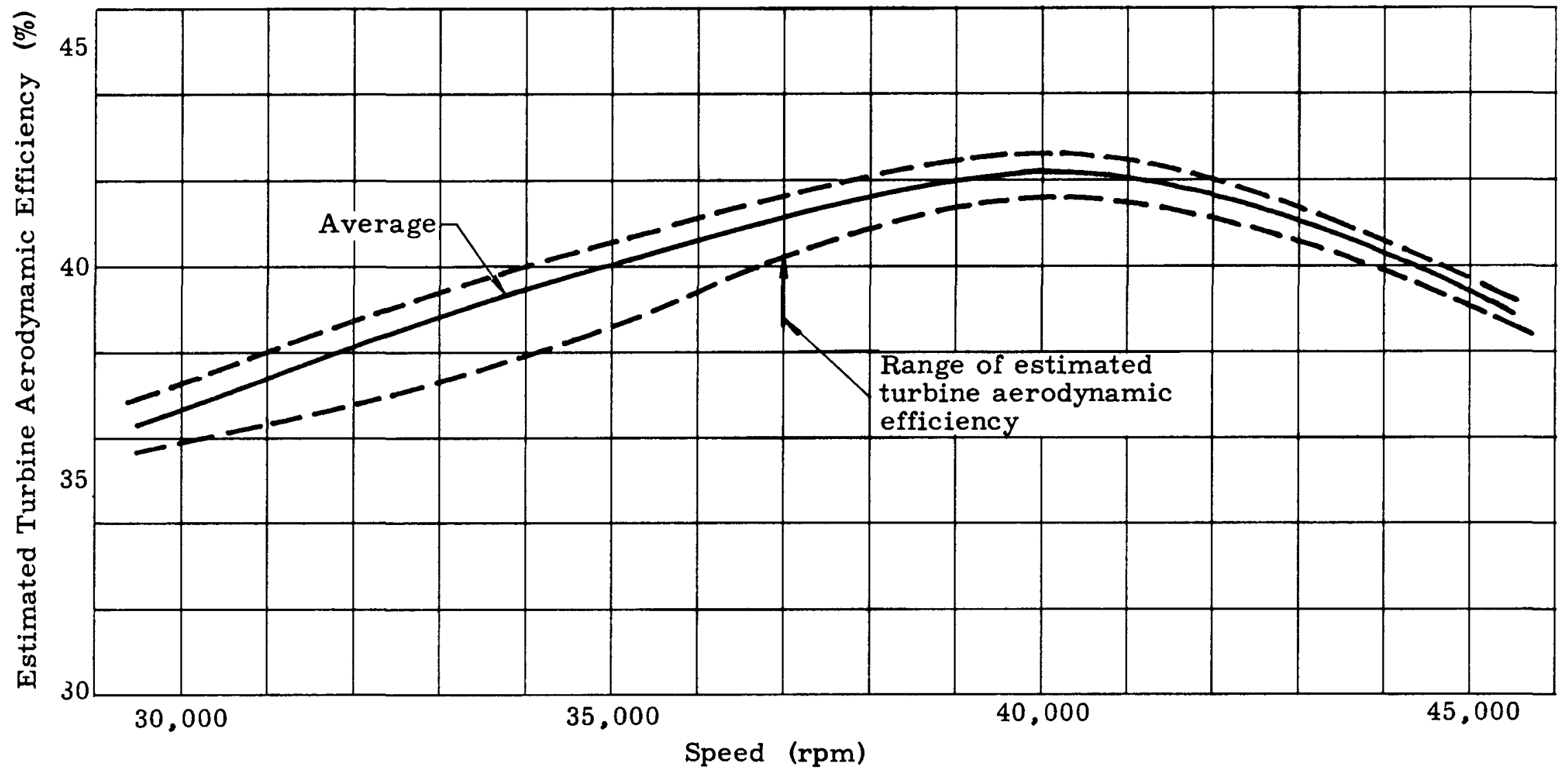

Fig. 7. Estimated Turbine Aerodynamic Efficiency Versus Rotational Speed 
TABLE 5

Comparison of Experimental and Design Specification Prototype Test Package Turbine Aerodynamic Performance

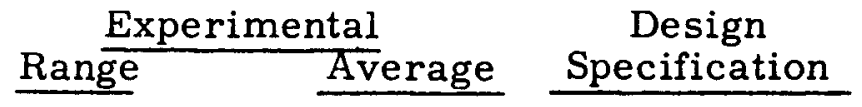

Inlet total pressure (psia) 206 to 211

1280 to 1296

1289

1300

( F)

Rotation speed (rpm)

$P_{\text {exhaust }}$ (psia)

Turbine flow $(\mathrm{lb} / \mathrm{sec})$

Aerodynamic power

(watts)

40,000 to 40,100

40,020

40,000

1.77 to 2.44

2.04

2.06

0.0305 to 0.0311

0.0308

0.0311

660.8 to 700.5

654

Aerodynamic efficiency

$(\%)$

40.0

\section{B. FUTURE GROWTH POTENTIAL}

The maximum turbine power, 800 watts, may be obtained by a slight modification in the original design, namely, a small reduction in turbine third-stage nozzle blade height. However, it cannot be accurately determined whether plugging of the third-stage nozzle will have the same effect as lowering the blade height to approximately 0.102 inch. The effect of the partial admission on the third stage, which was designed to have reaction in the rotor, is very uncertain. Further optimization would be found only in extrapolation of previous results and a corresponding design revision. 
page blank 


\section{POWER CONVERSION SYSTEM ALTERNATOR DEVELOPMENT}

(REF。5)

The SNAP I power conversion system alternator is a permanent magnet design which is simpler and more reliable than the conventional wound field alternator. A major advance in the state of the art of high temperature materials allowed the alternator stator windings to operate at high temperature, thus eliminating the need for alternator cooling.

During the alternator development program, several design concepts were evolved, and their performance was evaluated. As a result, an alternator was designed which performed satisfactorily in both component and system tests. Although this unique application placed stringent operating conditions on the alternator, it was shown that a permanent magnet alternator could operate satisfactorily in a high temperature mercury vapor atmosphere under severe mechanical stress conditions. The development program also showed that the performance of the alternator agreed quite closely with design conditions.

This report traces the developmental history of the SNAP I permanent magnet alternator. The original requirements and a discussion of the design selected to fulfill these requirements are presented. Representative performance data, such as voltage regulation, harmonics and efficiency, are presented for each stator design. The design and performance of the rotor are discussed, and the bore seal and motor startup problem areas are explained. A description of the test facilities for the alternator development program is also included. Finally, conclusions and suggestions for design improvements to further increase performance are presented. The alternator components developed for this program are shown in Figs. 8 and 9.

\section{A. OBJECTIVES AND RESULTS}

To arrive at a set of design specifications, it was necessary to consider the operational requirements of the alternator. The environment imposed on the alternator made a permanent magnet, brushless machine attractive since the specialized environment to ensure long brush life is not present, and a permanent magnet can operate satisfactorily at high temperatures. Operation at $600^{\circ}$ to $700^{\circ} \mathrm{F}$ does produce some loss of magnetization, but this effect can be considered in the magnet design. In addition, all components must be capable of operating in the presence of mercury vapor.

As a result of these considerations and preliminary design studies, the design specifications shown in Table 6 were formulated。 


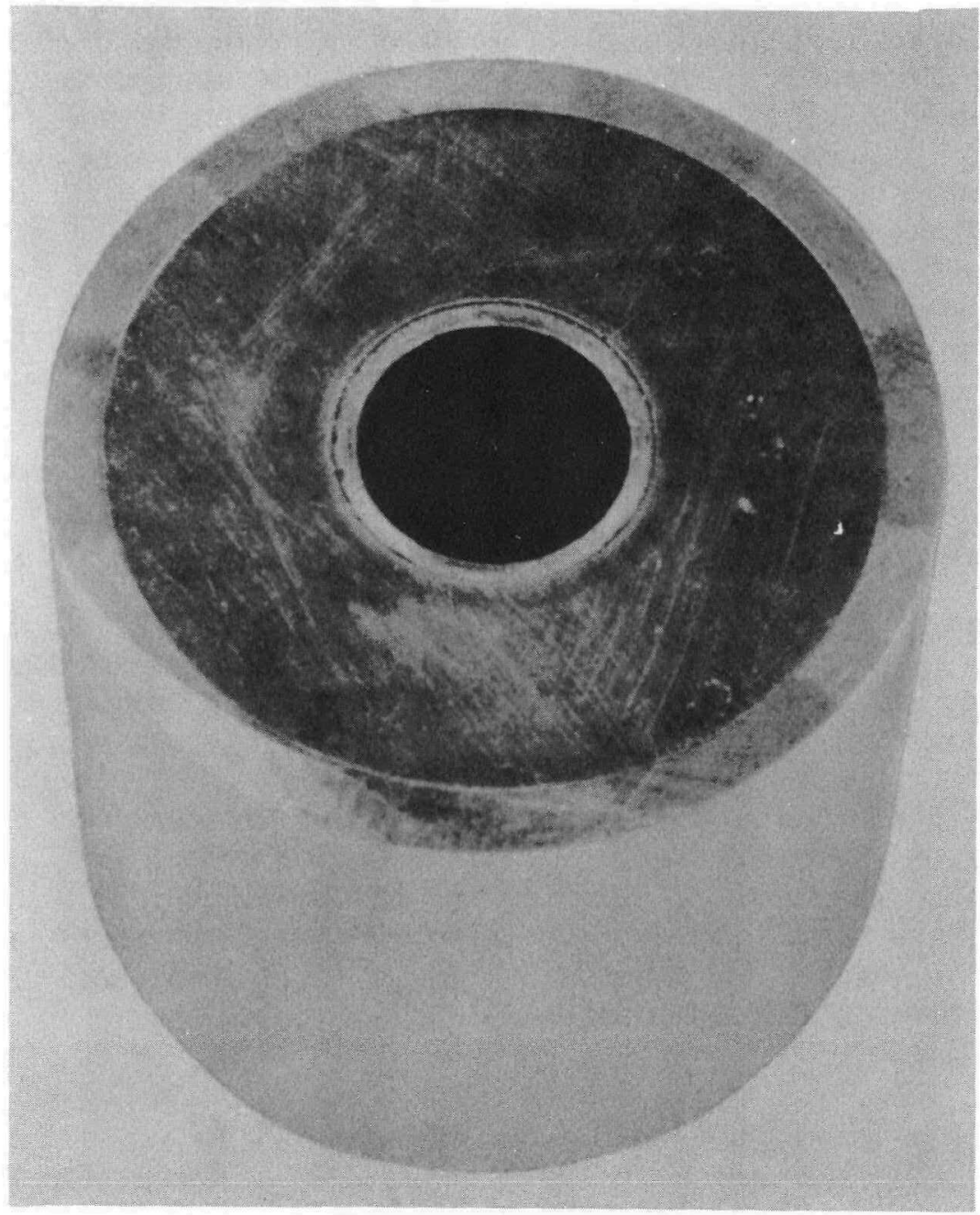

Fig. 8. SNAP I Permanent Magnet Alternator Rotor 


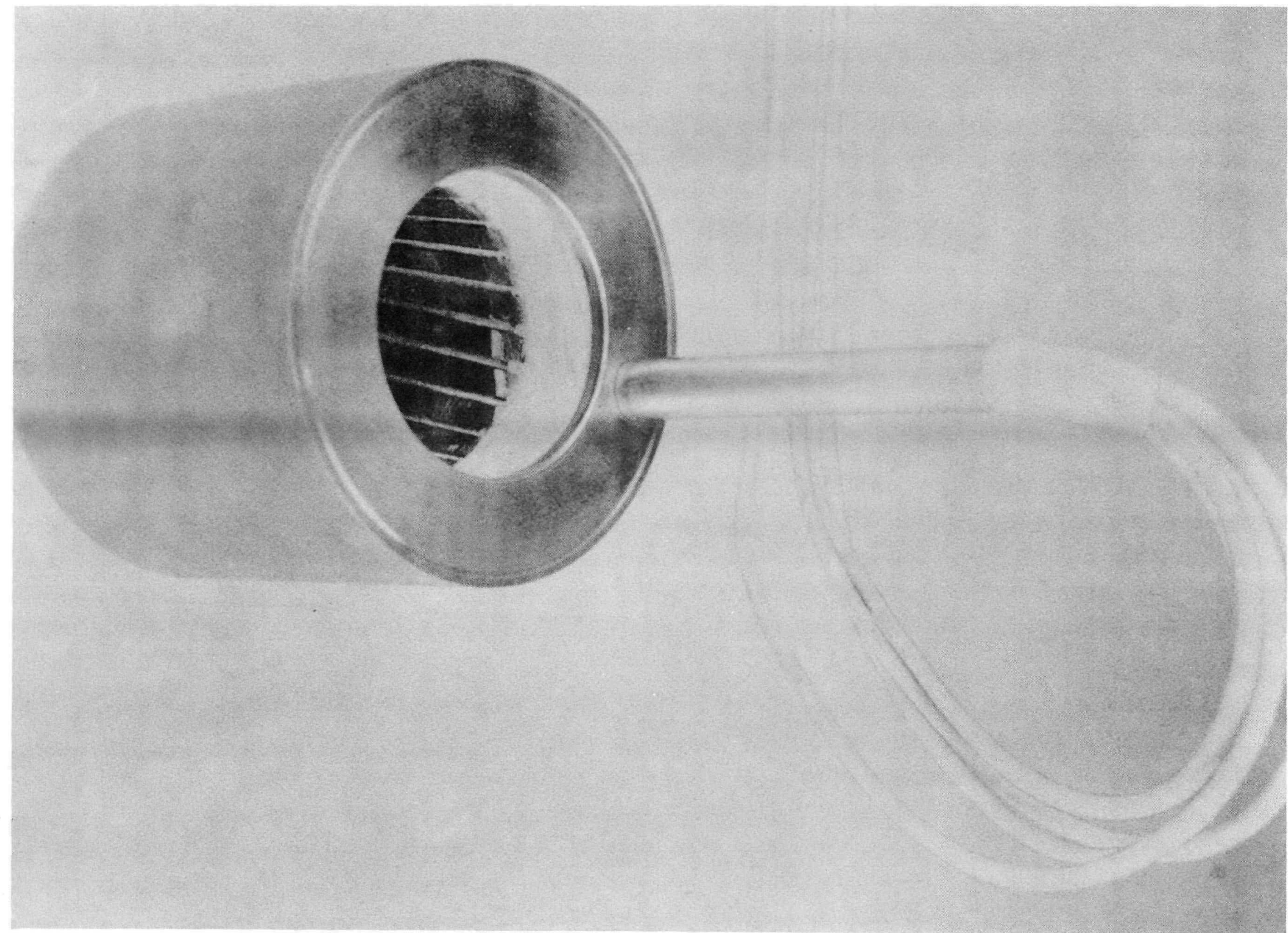


TABLE 6

Final Alternator Design Specifications

Electrical output

Voltage

Frequency

Power factor

Voltage regulation

Harmonics

Efficiency

Overload

Motor startup

Radio interference

Coolant
530 watts, single phase

$115 \times \pm 2 \%$ at operating temperature

$2000 \pm 2.5 \%$ (controlled externally)

Must meet design requirements at $0.80 \pm$ 0.02 lagging

Due to changes in load from 0 to $100 \%$ of nominal load at nominal frequency and power factor, voltage regulation must be less than $25 \%$; due to frequency changes, voltage regulation must be less than $2.5 \%$

Less than $7 \%$ when operating into linear load

$85 \%$ (design objective)

Must be capable of sustaining steady current overload $20 \%$ above nominal with no permanent effects on performance when operating into linear load of not less than an $0.80 \mathrm{pf}$

Must be capable of operating as motor to start the package; during startup and load stabilization, must be capable of current overload of $50 \%$ of nominal

Must meet requirements of MIL-I-6181B

Must operate without coolant as long as alternator winding temperature does not exceed $550^{\circ} \mathrm{F}$

A stator of the final design was constructed, and the performance is plotted in Figs, 10 and 11; additional data are shown in Table 7. The voltage regulation was approximately $31 \%$, and the efficiency improved over earlier designs by 7 to $82.5 \%$. The rotor pole face losses were decreased from about 110 watts for earlier designs to approximately 50 watts. 


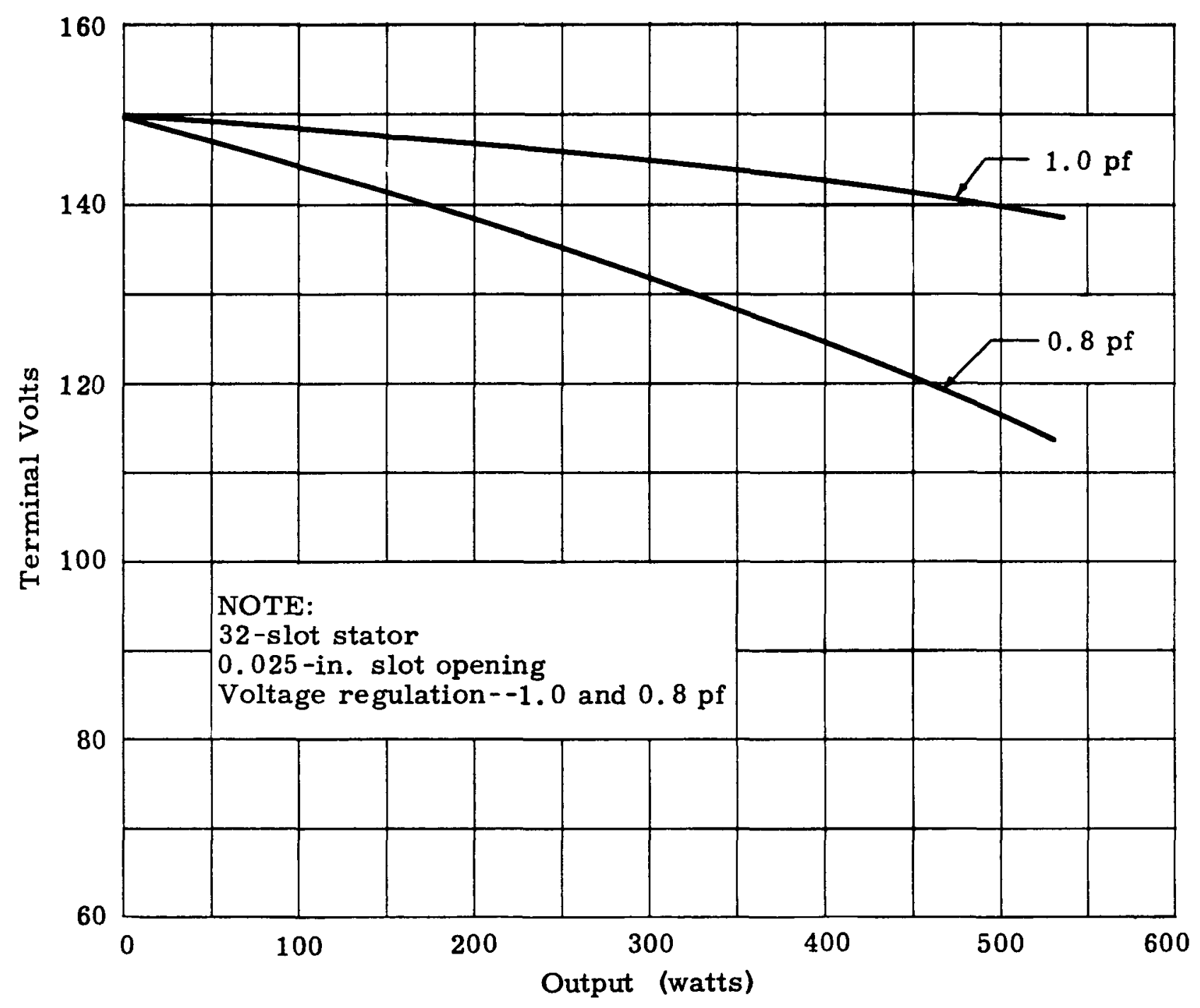

Fig. 10. SNAP I Alternator Performance 


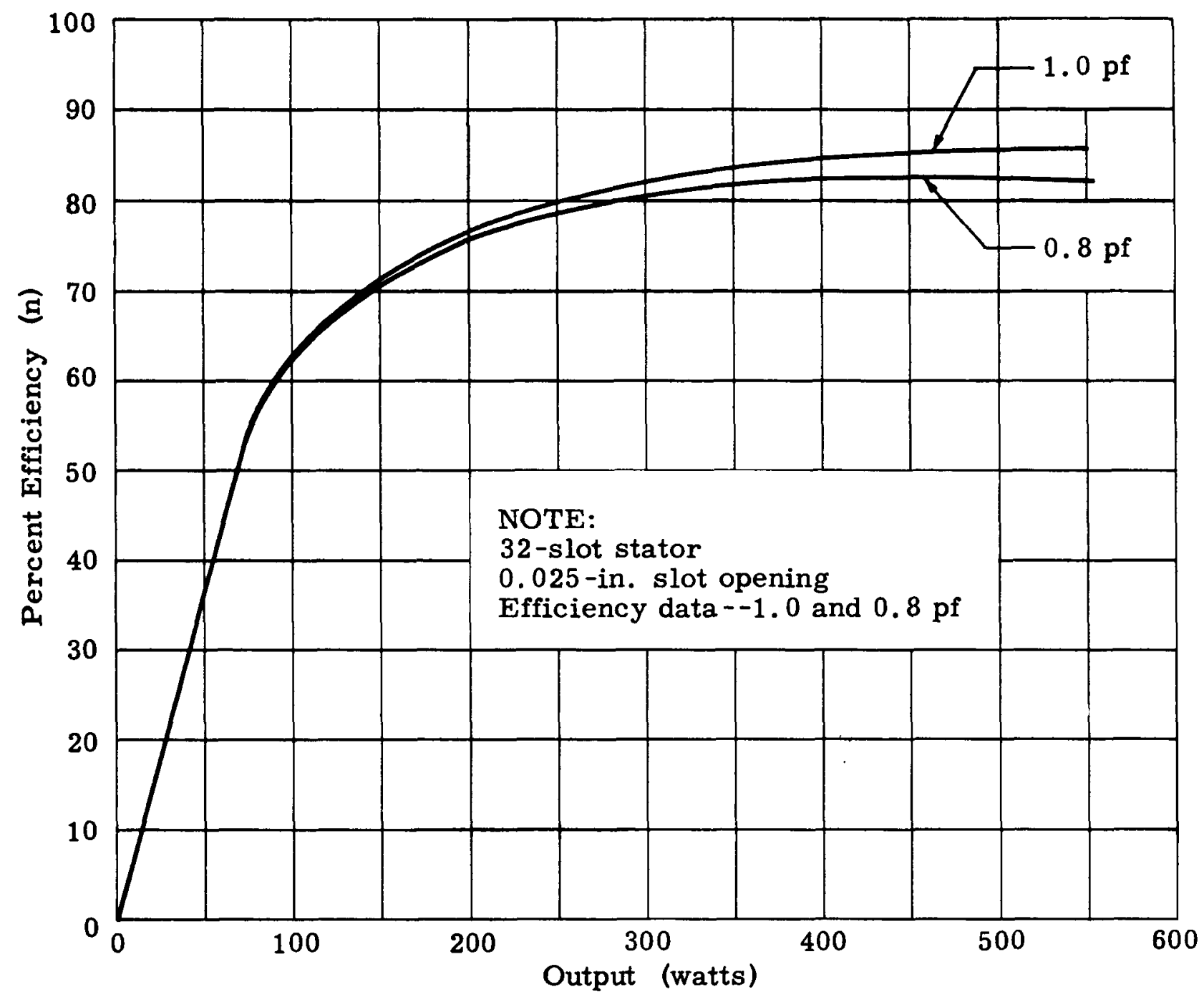

FIg. 11. SNAP I Alternator Performance 


\section{TABLE 7 \\ Final Alternator Performance Data}

\begin{tabular}{|c|c|c|c|c|}
\hline & $\begin{array}{c}\text { Load } \\
\text { (watts) }\end{array}$ & & $\begin{array}{l}\text { Power } \\
\text { Factor } \\
\end{array}$ & $(\%)$ \\
\hline \multirow{2}{*}{ Voltage regulation } & 530 & at & 1.0 & 7.9 \\
\hline & 530 & at & 0.8 & 31.5 \\
\hline Total distortion & 530 & at & 0.8 & 5.5 \\
\hline \multirow{2}{*}{ Efficiency } & 530 & at & 1.0 & 86.0 \\
\hline & 530 & at & 0.8 & 82.5 \\
\hline
\end{tabular}

A permanent magnet rotor was constructed for operation in a high temperature mercury vapor atmosphere. This rotor will function satisfactorily under the high mechanical stress conditions that are present. The performance of the rotor was reasonably close to design predictions.

The stator for the alternator also performed fairly satisfactorily under the adverse environment. Although all performance objectives were not met, the efficiency of $82.5 \%, 2.5 \%$ below the design objective, was the only notable deficiency in performance. Because the alternator load will probably be constant, the voltage regulation was not considered a serious problem。

The bore seal was probably the greatest problem area. Although a leaktight bore seal has been realized, the fabrication methods leave much to be desired. Future work will be required to guarantee the integrity of the seal.

The motor startup capability was a partially unresolved problem area。 However, with a properly designed power supply of sufficient capability, it is thought that satisfactory startup can be accomplished。

\section{B. FUTURE GROWTH POTENTIAL}

Alternator efficiency can be raised to the required objective of $85 \%$ by a slight design change in the stator lamination and by a $10 \%$ increase in the stator stack length. An increase in efficiency to nearly $90 \%$ can probably be realized if the alternator is loaded two phase. Although connected single phase, no design changes would be required in switching to two-phase loading because the alternator has been designed as a two-phase unit。 
page blank 
VII。 POWER CONVERSION SYSTEM PUMP DEVELOPMENT (REF。6)

The SNAP I mercury pump was required to operate at high speeds and produce a high head with low flow and a very low inlet pressure for long periods of unattended operation. Considerations of cavitation, small size, low specific speed, high fluid density and the required extrapolation of empirical pump design constants meant that the state of the art in pump design would be significantly advanced by the successful attainment of these requirements.

The SNAP I pump development program was established to determine feasibility, correlate anlytical and experimental results, and develop a pump capable of meeting system design specifications. Figure 12 shows the pump hardware used in this program.

\section{A。 OBJECTIVES AND RESULTS}

The pump for the SNAP I power conversion system was required to take the low pressure mercury from the subcooler and supply it continuously at high pressure to the boiler and the turbomachinery (see Fig. 13)。 The pump had to accomplish this task with no external leakage and at a minimum weight. The specific design objectives of the pump changed as the SNAP I power output requirements were increased and as bearing design was formulated. This overall system development resulted in the specific final pump design requirements listed in Table 8 。

The final pump configuration was a jet-boost stage combined with a four-vaned radial impeller mounted on an overhung shaft.

TABLE 8

SNAP I Pump Requirements

\begin{tabular}{|c|c|c|c|c|}
\hline & Initial & Interim & Interim & Final \\
\hline Fluid & Liquid $\mathrm{Hg}$ & Liquid $\mathrm{Hg}$ & Liquid $\mathrm{Hg}$ & Liquid $\mathrm{Hg}$ \\
\hline Shaft speed (rpm) & 40,000 & 40,000 & 40,000 & 40,000 \\
\hline $\begin{array}{l}\text { Discharge pressure } \\
\text { (psia) }\end{array}$ & 230 & 250 & 250 & 287 \\
\hline $\begin{array}{l}\text { Net developed head } \\
(\mathrm{ft})\end{array}$ & 40 & 43.3 & 43.3 & 50 \\
\hline Inlet pressure (psia) & 1.86 & 1.86 & 1.86 & 1.86 \\
\hline
\end{tabular}


TABLE 8 (continued)

$\underline{\text { Initial Interim } \text { Interim Final }}$

Inlet temperature

$\left({ }^{\circ} \mathrm{F}\right)$

330

330

330

330

Design capacity

(lb/min)

2

8

15

12

(gpm)

0.0182

0.0727

0.1364

0.1091

Power limit

(maximum) (watts)

20

80

100

100

Life (days)

60

60

60

60

Impeller specific speed

340

640

875

705

Pump efficiency

25

25

25

25

Pump type

Shaft

Shaft and slinger

$\begin{array}{ll}\text { Spiral } & \text { Jet-centri- } \\ \text { and } & \text { fugal } \\ \text { centri- } & \\ \text { fugal } & \end{array}$

The experience gained from the preliminary SNAP I pump development program indicated that it was possible to design a pump to operate at a very low inlet pressure. The test data also indicated that a jet pump was needed to raise the impeller inlet pressure to a value high enough to eliminate cavitation.

An evaluation of the effect of temperature on pump performance was obtained in the pump component test rig. Figure 14 shows the results of the tests on the four-vaned impeller in the jet housing with a constant jet pump supply pressure of 200 psia and $2.1-\mathrm{lb} / \mathrm{min}$ flow with $75^{\circ}$ and $330^{\circ} \mathrm{F}$ mercury inlet temperatures. It should be noted that the pump performance decreases slightly with the increased inlet temperature at 40,000 rpm and 2.0-psia inlet pressure with a fixed jet pump flow of $2.2 \mathrm{lb} / \mathrm{min}$. As the development progressed, the full pump discharge pressure was used to drive the jet pump, and a higher level of overall pump performance was obtained.

Experimental results have verified that the jet-boosted centrifugal mercury pump performance has exceeded system design specifications. The overall pump efficiency at the design point was $27 \%$ with a corresponding shaft power consumption of 70 watts. 


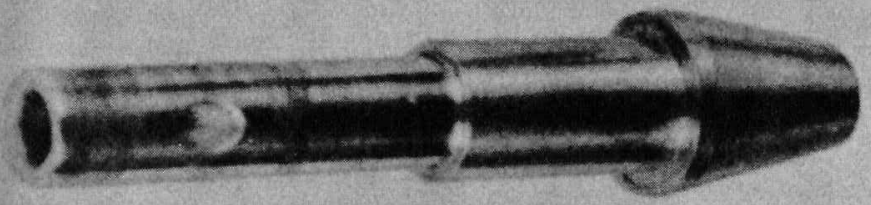

Shaft
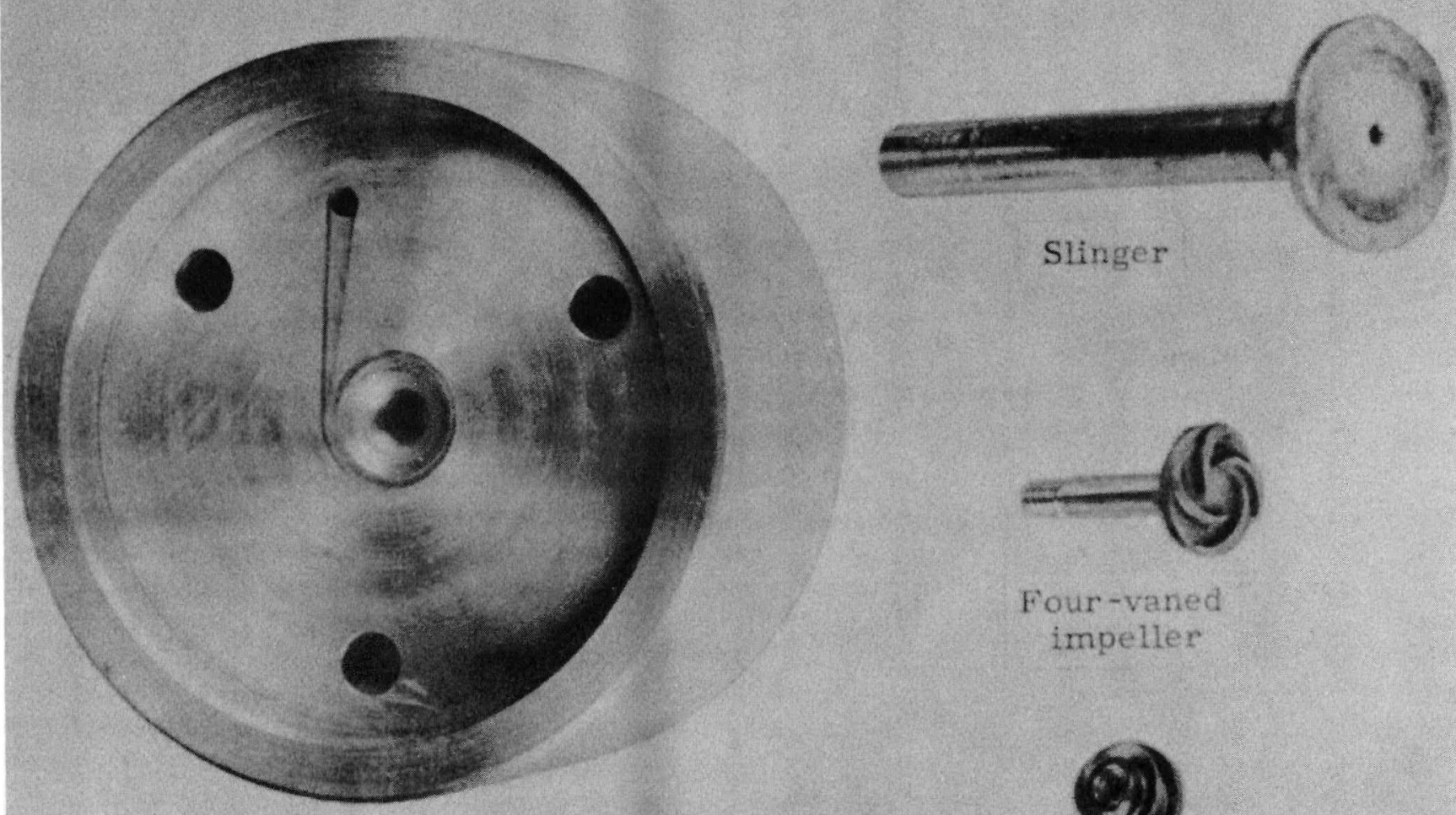

Impeller pump housing

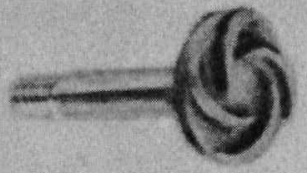

Four-vaned

impeller

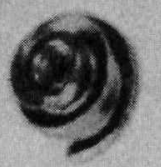

Two-blade spiral

Fig. 12. SNAP I Pump Components 


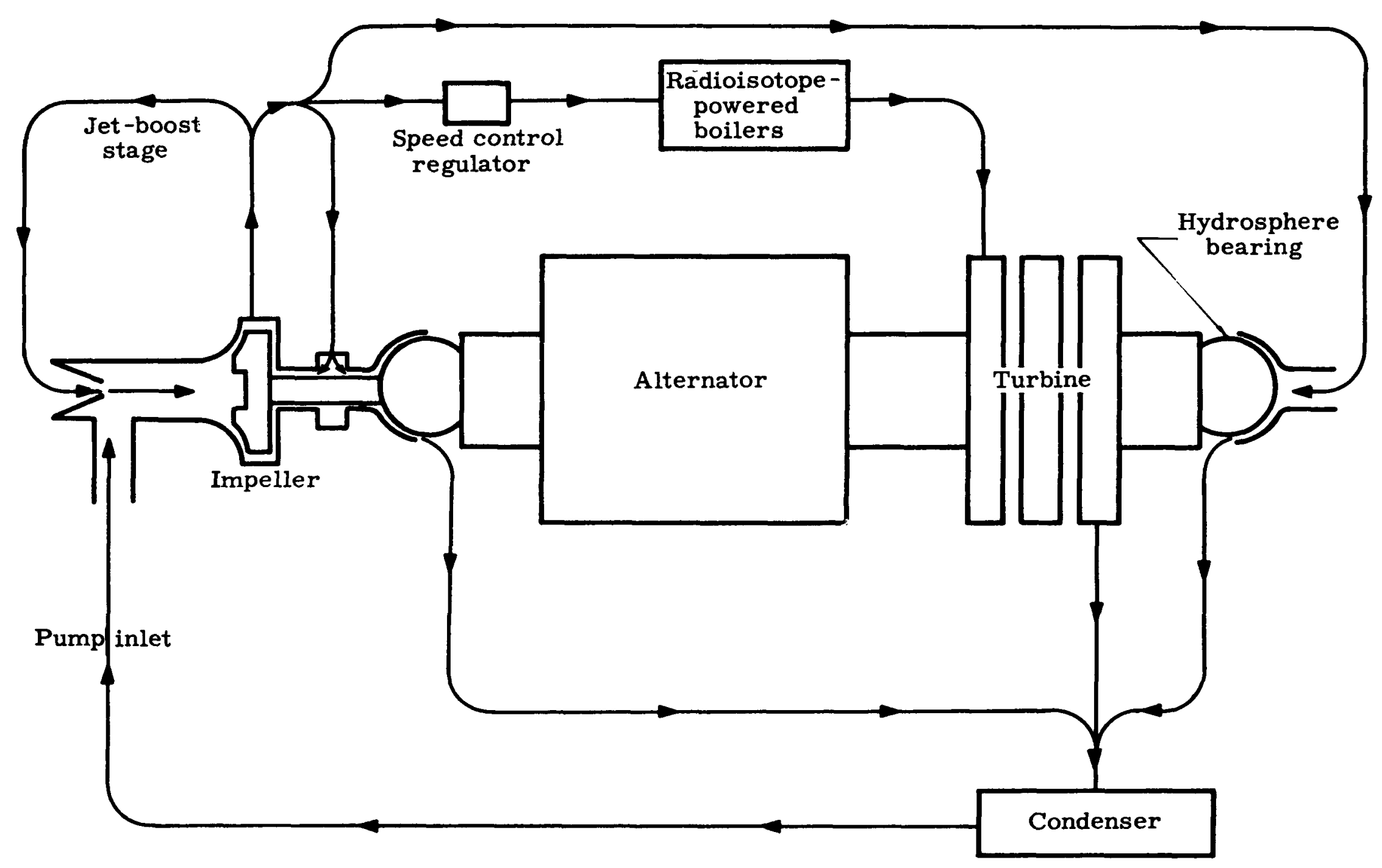

Fig. 13. SNAP I Power Conversion System Flow Schematic 


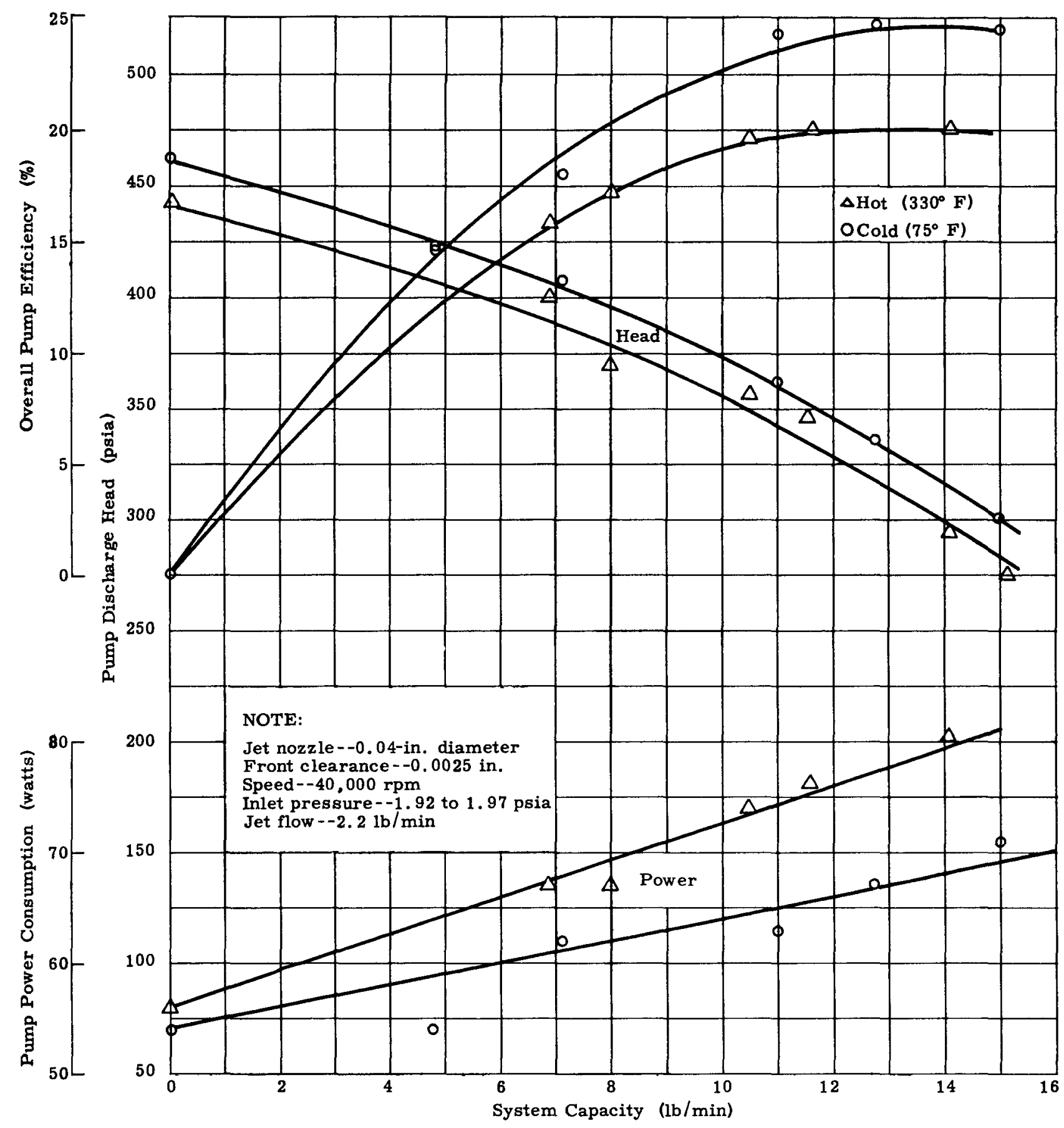

Fig. 14. Jet Centrifugal Pump Performance Curves 
page blank 
VIII. POWER CONVERSION SYSTEM BEARING DEVELOPMENT (REF . 7)

The SNAP I bearing development program consisted of the analysis, design, fabrication and testing of several types of hydrosphere bearings. Preliminary analysis and experimental testing indicated that a hydrosphere bearing (a mated spherical journal and hemispherical socket) would best satisfy the SNAP I requirements. Primary design considerations were reliability, low power loss, sufficient load capacity and minimum lubricant flow requirements. The hydrosphere bearing offers combined thrust and radial load capacity, good dynamic stability, misalignment capability, close control of clearances for other rotating components and utilization of the working fluid as a lubricant.

\section{A. OBJECTIVES AND RESULTS}

Rankine space power conversion systems require turbomachinery bearings that will allow long, consistent, reliable action. The bearings chosen must provide a minimum parasitic torque when exposed to any of the following loads:

(1) Axial and radial loads imposed by the shaft-mounted equipment。

(2) Possible loads due to thermal and loading deformations.

(3) Acceleration loads.

(4) Vibration loads。

(5) Gyroscopic loads。

The ability of the bearing to carry these loads is not the only criterion for choice. The bearings must also provide:

(1) Accurate positioning of the shaft and turbine seals.

(2) Small variation in fluid leakage from the cold start to the more stable running conditions.

(3) A seal for the working fluid or utilize it as the lubricating fluid.

(4) Sufficient allowance for reasonable amounts of lubricant contamination.

(5) Allowance for changes in angular velocity and load. 
Using these requirements and considerations plus overall system requirements, the design objectives shown in Table 9 were formulated.

$$
\frac{\text { TABLE } 9}{\text { Bearing Design Objectives }}
$$

Speed

Power absorption (2 bearings)

Flow (2 bearings)

Lubricant

Lubricant supply pressure

Lubricant supply

temperature

Life

Running eccentricity
$40,000 \mathrm{rpm}$

40 watts

$10 \mathrm{lb} / \mathrm{min}$

Liquid mercury

250 psia

$350^{\circ} \mathrm{F}$

60 days

The following conclusions have been reached concerning hydrosphere design and performance:

(1) Axial and radial loads of the magnitude encountered in the SNAP I application can be sustained.

(2) Power losses as determined by more refined analysis and by test data are higher than originally predicted ( 40 watts estimated, 110 watts by test)。

(3) Dynamic stability of the lubricant film has been demonstrated consistently。

(4) Flow rates are not excessive and can be varied by changing radial or axial clearance and/or flow restriction dimensions.

(5) Small angular misalignment of the shaft can be tolerated without affecting performance.

(6) The bearing is sensitive to small clearance changes which may arise from differential thermal expansion, from buildup of lubricant contaminant or from inadequate precision during fabrication. 
(7) Some hydrostatic support of radial loads has been demonstrated.

(8) Axial grooves in the socket tend to reduce the radial loadcarrying capacity.

(9) Contact stresses at nominal radial loads are high but can be reduced to tolerable levels by proper design of the socket equator.

(10) The best bearing materials which were wear tested for startup and shutdown requirements were tungsten carbide and titanium carbide. Capsule tests for mercury compatibility at $650^{\circ} \mathrm{F}$ for 1000 hours indicate some attack on the bonding matrix. However, for the lower temperatures anticipated in the bearing, compatibility and corrosion of the carbides do not appear to have a significant effect on bearing life 。

\section{B。 FUTURE GROWTH POTENTIAL}

Further development work is required in the following areas:

(1) Reduction in power loss. The most promising method of reducing power loss, although not fully investigated by test, appears to be a reduction in socket arc length in the axial direction.

(2) Increase in bearing tolerability to clearance reduction caused by contamination and differential thermal expansion. From the bearing viewpoint, reduction in the production contaminants by the system, a means for their exclusion from the bearings and reduction of thermal gradients in the package would be desirable.

(3) Increase in flow restriction tolerability to flow area reduction as a result of contamination. 
page blank 
IX. POWER CONVERSION SYSTEM CONTROL DEVELOPMENT

(REF。8)

The results and efforts of analysis work and computer studies on the controls for the SNAP I power conversion system are presented in this report. The areas of activity discussed include preliminary analysis of the system and controls requirements, determination of system specifications, two complete computer simulations of the system with the second simulation incorporating all available component data, a development and test program for all controls hardware and an investigation of special system and hardware requirements. A description of test and prototype hardware and performance data is also presented. The satisfactory conclusion to the controls effort is substantiated by the demonstrated ability of all major components to function separately in test stands or collectively in system tests for periods of several thousand hours.

The control package consisted of two parts: a pressure regulating throttle, and a speed sense and amplifier. The pressure regulator was utilized in the line feeding the boiler to eliminate an inherent instability in the system due to a positive feedback condition in the pump loop. The speed sense and amplifier were used to detect errors in system operation and to provide a corrective signal to reset the operating point of the regulator. This combination of regulator and speed sensitive feedback provided satisfactory steady-state operation and corrected for minor system disturbances or changes in component characteristics.

\section{A。 OBJECTIVES AND RESULTS}

At the beginning of the SNAP I program, it was recognized that the controls area could be one of major importance in the successful development of a conversion system utilizing mercury vapor as the working fluid. Early investigations of the system were made in the following areas to establish a controls program:

(1) System specifications.

(2) Load variations.

(3) Steady-state system analysis。

(4) Dynamic systems analysis using Laplace and differential solutions.

(5) Controls component evaluations. 
(6) Effects of mercury inventory variations.

(7) Summary of system component performance to be used in preparing an analog computer simulation.

(8) System startup and shutdown concepts.

The first step in the control study program was to define as clearly as possible the exact system requirements to which the control must adhere. Once this was established, it was then necessary to define the system characteristics with which the control must work. Finally, a description of the system was obtained in a form suitable for control analysis.

To achieve a power conversion unit of the smallest size and weight, it was desirable to maintain a constant input and output power。 One of the objectives of the control study was to achieve such a system despite known variations in the power source and the load which could be defined mathematically. There were, in addition, random disturbances to the system which could not be predicted. It was necessary that the control system be capable of performing properly when subjected to both the normal and random system disturbances.

It was determined that the basic uncontrolled system was inherently unstable because of a positive feedback through the pump-boiler-turbine loop. The positive feedback effect arose since, if turbine speed decreased, the pump speed and outlet pressure decreased also. Thus, boiler inlet and, consequently, turbine inlet pressures decreased, causing a further decrease in turbine and pump speed. This effect continued to zero speed. An opposite effect occurred when the turbine speed increased from the steady-state value.

Elimination of this positive feedback through the pressure loop was therefore mandatory for system stability。 To study the effects of system disturbances on the basic system, it was necessary to open the pressure loop and assume a perfect pressure regulator which would ideally hold system pressure constant or to incorporate a pressure regulator with a negative characteristic. The more negative the characteristic of the regulator, the greater the system stability within gain limits

Due to the problems associated with developing a regulator to operate in the high temperature mercury vapor atmosphere at the boiler outlet, studies were conducted with the regulator on the boiler inlet. Because of the small boiler inventory and the nearly constant boiler wall temperature, it was possible to demonstrate that any pressure transient induced in the liquid phase of the boiler would be felt in a very short time as a change in the pressure of the vapor fed to the turbine. 
Analytical, experimental and simulation studies conducted resulted in a thorough understanding of the problems associated with the operation of the SNAP I space power system.

Based upon the system specifications originally established for the SNAP I power conversion system and upon the specifications established from the computer studies relative to control components, all requirements were satisfactorily met。

Test and prototype hardware were designed and fabricated to satisfy all requirements. Preliminary breadboard tests and system tests have demonstrated the ability of the SNAP I turbomachinery controls hardware to function satisfactorily for periods much longer than the 60-day requirement originally specified. 
page blank 
X. POWER CONVERSION SYSTEM CONDENSER-RADIATOR DEVELOPMENT

(REF。9)

The development of a space condenser concept to reject heat by radiation and function in the absence of gravity was one of the initial endeavors of the SNAP I program. Analysis and test of this concept have continued throughout the program. It was found, in the early part of the study, that the heat transfer aspects of a space condenser were secondary to the fluid mechanics problems to be solved. Efforts were directed toward analytical and experimental investigations of the fluid mechanics problems for a condenser operating in a gravity-free environment. An analysis based on two-phase flow experimental data was applied to condensing along with a theoretical criterion for stability. The theory was verified in experiments with condensing steam. A glass test rig was fabricated to permit observation of mercury condensation. The dropwise condensation always observed in this rig was not completely analyzed, however, due to termination of the program.

A SNAP I one-quarter flow capacity flat plate mercury condenser was designed to permit investigation of heat transfer characteristics at simulated radiant heat fluxes and vapor-liquid inventory distributions. It was confirmed that condensing heat transfer coefficients obtained with this condenser were sufficiently high to represent negligible resistance to heat transfer compared to the outside radiation heat transfer coefficient.

A compact air-cooled mercury condenser was designed for use in the SNAP I ground test system tests. This condenser has performed very satisfactorily in the power conversion system testing.

\section{A. OBJECTIVES AND RESULTS}

The SNAP I condenser was required to condense $1.87 \mathrm{lb} / \mathrm{min}$ of mercury vapor flow from the turbine and to maintain a pump inlet pressure of $1.86 \mathrm{psia}$. The subcooler, an integral part of the condenser system, was required to subcool the condensate and the bearing liquid mercury flow of $10 \mathrm{lb} / \mathrm{min}$ to a temperature of $350^{\circ} \mathrm{F}$ 。 The subcooled liquid must then be supplied to the system pump at a constant pressure in a manner leaving no possibility for vapor to enter the pump. The pressure drop from the condenser inlet pump was required to be less than 0.2 psi.

The heat of vaporization and the sensible heat which was removed from the mercury in the condenser and subcooler must be rejected by thermal radiation. The condenser-radiator was required to have the 
shape of a hollow cylinder to fit the satellite vehicle and to have a surface area for radiation of no more than 19.5 square feet.

Conclusions reached as a result of this program were:

(1) For a plate-type radiating condenser, the resistance to heat transfer of the condensate film is negligible compared to the resistance of the radiating surface. For condensing mercury, the heat transfer coefficient is approximately $1000 \mathrm{Btu} / \mathrm{hr}-\mathrm{ft}^{2}-{ }^{\circ} \mathrm{F}$.

(2) In a low pressure level condenser, stratified laminar flow is desirable because of the resulting low pressure drop and the stable flow regime free from slugging.

(3) For a wetting fluid, the criterion for stable flow is that the Reynolds and Weber numbers be of the order of unity. This criterion is easily accomplished by the addition of internal fins in the mercury passages.

(4) The Martinelli correlation for pressure drop is applicable to condensing a wetting fluid. The correlation has not been verified for mercury on steel, a nonwetting case.

(5) The condenser-subcooler area required for the SNAP I system can be made to fit into the specified area by judicious selection of the radiative properties of the radiator surface. 
XI。 POWER CONVERSION SYSTEM MATERIALS DEVELOPMENT

$\underline{\text { (REF. 10) }}$

Because of the environmental conditions imposed on the SNAP I power conversion system, it was necessary to conduct a program to determine the materials to be used in fabricating the turbomachinery power conversion system. The materials had to be capable of operation for extended periods of time in a high temperature mercury atmosphere and possess such desired physical properties as strength, ease of fabrication and dimensional stability. The very small operating clearances resulting from miniaturization of the components made it imperative that formation of any corrosion products be minimized to avoid the plugging of small flow passages and the interference of mating parts. In addition, nonmetallic materials had to be evalsated to provide a reliable insulation system for the electrical components and a method for ensuring that mercury did not enter the stator windings of the alternator.

\section{A。 OBJECTIVES AND RESULTS}

Metallic materials were investigated to determine their resistance to corrosive attack by mercury at the high temperatures involved and the effect of mass transfer due to temperature and concentration gradients existing in the system. The materials evaluated included the refractory metals, carbon steels and the Type 300 and 400 series stainless steels. As a result of the metallic materials effort, it was concluded that, for the SNAP I system, redisposition of the corrosion contaminants generated produced a more severe problem than the problem arising from the loss of structural material.

Specific conclusions drawn from this program were:

(1) The loss of the container wall due to mercury corrosion at temperatures up to $785^{\circ} \mathrm{F}$ is not sufficient to cause a stress problem for the materials tested with the exception of unalloyed titanium.

(2) The quantity of corrosion contaminants generated in a mercury system can become a major problem if small passages are present which can become obstructed.

(3) Corrosion of the chromium-nickel-iron stainless steels is much more severe than the corrosion of the chromium-iron stainless steels at test temperatures up to $1000^{\circ} \mathrm{F}$ 。 
(4) The refractory metals, titanium carbide and tungsten carbide are highly resistant to mercury corrosion as indicated by 12 -day test data。

A nonmetallic materials program was conducted to develop suitable insulation and sealing materials for the alternator stator. It was established that the materials and fabrication techniques developed could satisfactorily protect the alternator stator in the SNAP I environment.

The nonmetallic materials development program has made available information which permitted the specification of the materials and processing needed to meet the requirements of the SNAP I system. The program, though necessarily short, did serve to advance, or perhaps even pioneer, the state of the art insofar as development of electrical equipment for use in a mercury environment at high temperatures is concerned。

It was established that a number of materials are available for use as electrical insulation and potting compounds in the SNAP I environment. Several of these materials also are capable of preventing penetration of mercury into sensitive portions of the alternator stator. Although porous to mercury, several of the commercially available potting compounds have shown the required thermal stability。 The Mycalex glass-bonded mica compounds, Corning No.95 solder glass and mineral-filled Dow Corning DC-7521 resin have demonstrated both thermal stability and the ability to act as barriers to mercury。

The primary problem area still existing is the means by which these materials may be incorporated into the fabrication of a leaktight stator assembly. In addition, there is little doubt that the evaluation program has served to point to several classes of materials which may be useful for the SNAP I system and that these groups of useful materials have only been touched upon. More evaluation work will be required to fully exploit the leads supplied by the test program。

\section{B。 FUTURE GROWTH POTENTIAL}

Future work may be divided into three phases. First, an expanded test program may be instigated to evaluate all materials presently used on the SNAP I system to determine their actual temperature capabilities, dielectric properties at elevated temperatures and the long term effect of the SNAP I environment on all important physical properties. Secondly, a program should be conducted to fully evaluate all materials of potential value in the system. Finally, materials which have the required physical characteristics should be studied to determine the fabrication techniques required to incorporate them into the overall system so as to take advantage of their desirable properties. This is particularly true of vitreous materials of the Mycalex and Corning solder glass types, which offer optimum physical properties but the full exploitation of which awaits the development of better application and fabrication techniques. 


\section{XII。CONCLUSIONS}

The results of the system and components development are:

(1) Tests have shown that a 500-watt, radioisotope-powered, turboelectric power conversion system for space applications is feasible. An endurance test run of 104 days has demonstrated that the 60-day life objective can be achieved.

(2) Electrically heated, half-power mercury boilers were fabricated and tested at design conditions of $0.935-1 \mathrm{~b} / \mathrm{min}$ mercury vapor flow, 210-psia fluid discharge pressure and $1300^{\circ} \mathrm{F}$ fluid discharge temperature. The maximum internal pressure drop specification of 15 psi was also achieved.

A radioisotope heat source was not mated to the boiler because of program termination although complete design and partial fabrication did not expose any major obstacles. Integration of the parallel flow dual boilers in the complete system tests indicated that additional development effort is required to ensure $100 \%$ dry mercury vapor at the turbine inlet and nonpulsating flow conditions.

(3) High temperature $\left(1350^{\circ} \mathrm{F}\right)$ mercury loop tests indicated that the Type 300 series stainless steels are the most suitable containment materials for two-phase mercury flow. Additional endurance testing using close material and environmental control would be required to establish 60-day life material compatibility。

(4) The development of a three-stage, axial flow, impulse mercury vapor turbine was successful。 Original design objectives of $40 \%$ efficiency and 605-watt power output were exceeded by $2.3 \%$ and 77 watts, respectively. A maximum power of 800 watts can be obtained by moderate design changes to the third-stage turbine nozzle.

(5) A permanent magnet, brushless, uncooled alternator was developed for the SNAP I system. Although all performance objectives were not met, the efficiency of $82.5 \%, 2.5 \%$ below the design objective, was the only notable deficiency in performance. Because the alternator load will probably be constant, the voltage regulation was not considered a serious problem. Alternator efficiency can be improved to $85 \%$ by minor modifications to the stator. An efficiency approaching $90 \%$ can be realized by switching from single-phase to two-phase-loading. 
(6) Experimental results have verified that the jet-boosted centrifugal mercury pump exceeded the $25 \%$ design efficiency by $2 \%$. Power consumption exceeded the specified 34 watts by approximately 36 watts。

(7) Mercury-lubricated hydrosphere bearings were selected to support the turbomachinery rotating shaft. This design, utilizing 18-4-1 tungsten alloy tool steel for the ball and socket, proved satisfactory in component and system tests. Power loss exceeded the 40-watt design objective by 70 watts. Further development is necessary to reduce power loss and increase bearing tolerability to contamination.

(8) A turbomachinery speed control package, consisting of a pressure regulating throttle and a speed sense and amplifier, was developed for the power conversion system. Preliminary breadboard tests and system tests have demonstrated the capability of the SNAP I controls hardware to function satisfactorily for periods much longer than the 60-day requirement

(9) A space-oriented condenser-radiator "concept was developed which utilized a plate-type radiating condenser。 Tests were conducted which indicated the feasibility of the design approach。 A compact air-cooled condenser was also designed, and its performance was very satifactory in the power conversion system testing。

(10) Metallic and nonmetallic materials development programs were conducted in support of the turbomachinery power conversion system. In the metal studies, it was determined that redisposition of mercury corrosion contaminants produced more severe problems than the problems arising from the loss of structural material. The loss of the container wall due to mercury corrosion at temperatures up to $785^{\circ} \mathrm{F}$ will not cause a stress problem, particularly when using the chromium-iron stainless steels.

The nonmetallic materials development program satisfied the immediate needs of the SNAP I system. The Mycalex glass-bonded mica compounds, Corning No. 95 solder glass and mineral-filled Dow Corning DC-7521 resin have demonstrated thermal stability and mercury barrier capability。 


\section{XIII。BIBLIOGRAPHY}

1. "Proposal for Continuation of Development Effort on an Isotope Heat Source for an Auxiliary Power Unit Under Contract AT (30-3)-217," MND-1023, The Martin Company, 12 December 1956。SRD

2. "Statement of Work Covering Power Conversion System Development Effort to be Subcontracted for Five Month Period Ending June 31, 1957 - Prime Contract with AEC," MND-1033, The Martin Company, 16 January 1957。SDI

3. "Technical Proposal to WADC Covering Subcontract to Thompson Products on Project Pied Piper for a 5 Month Period Beginning February 1, 1957," MND-1037, The Martin Company, 22 January 1957. SRD

4. "Technical Statement of Work for WADC Contract Covering Support for Power Conversion System Development on APU for Satellite Application," MND-1039, The Martin Company, 25 January 1957. SRD

5. "Statement of Work to be Performed by Thompson Products Under Subcontract to The Martin Company for Power Conversion System Development - Contract Support Covered by WADC," MND-1039 (Revision 1), The Martin Company, 20 February 1957。SRD

6. "Technical Statement of Work for AEC Contract Covering Support for Power Conversion System Development on APU for Satellite Application," MND-1048, The Martin Company, 4 February 1957. SRD

7. "Technical Statement of Work for Contract Covering Power Conversion System Development," MND-1048 (Addendum 1), The Martin Company, 2 February 1957. SRD

8. "Technical Statement of Work to be Performed by Thompson Products Under Subcontract to The Martin Company for Power Conversion System Development - Contract Covered by AEC," MND-1048 (Addendum 2), The Martin Company, 20 February 1957. SRD

9. "Technical Statement of Work Covering Contract Extension with Thompson Products," MND-1108, The Martin Company, 13 June 1957. SRD

10. "Technical Statement of Work Covering Extension with Thompson Products, September 23, 1957 - Power Conversion System Development," MND-1108 (Supplement 1), The Martin Company。 SRD 
11. "Statement of Work on Development of Mercury Vapor Power Conversion System by $T_{\circ} P_{\circ}$ for The Martin Company (October 1, 1957 to June 30, 1958)," MND-P-1195, The Martin Company, 1 October 1957。SRD

12. "Overall Development Plan, SNAP I (October 1957 to December 1959)," MND-P-1207, The Martin Company。 SRD

13. "Program Objective and Development Plans, SNAP I," MND-P1227, The Martin Company. SRD

14. "Hazards Summary Report, SNAP I," MND-P-1229, The Martin Company, January 1958。SRD

15. "Description of Work - Fiscal 1959 and Fiscal 1960, SNAP I and SNAP III," MND-P-1298, The Martin Company, 30 March 1958 。 SDI

16. "Technical Highlights for Contract AT(30-3)-217 - a Narrative Summary of Accomplishments and Objectives for SNAP I and III Programs," MND-P-1318, The Martin Company。 SDI

17. "Supplemental Work Statement for Fiscal 1958," MND-P-1319, The Martin Company, 28 April 1958. SDI

18. "Program Plan for Contract AT (30-3)-217," MND-P-1416, The Martin Company, 4 June 1958. SDI

19. "SNAP I - Statement of Work - Power Conversion System (Thompson Products) July 1, 1958 to September 30, 1958," MND-P-1480, The Martin Company, 15 July 1959。SDI

20. "SNAP I - Statement of Work - Power Conversion System (Thompson Products) July 1, 1958 to September 30, 1958," MND-P-1487, The Martin Company, 30 June 1958。SDI 


\section{REFERENCES}

1. "SNAP I Power Conversion System Development," TRW, 20 June 1960.

2. "SNAP I Mercury Boiler Development," The Martin Company, June 1960.

3. "SNAP I Dynamic Mercury Loop Tests of Selected Materials," MND-P-2128, The Martin Company, March 1960.

4. "SNAP I Power Conversion System Turbine Development," ER-4051, TRW, 20 June 1960.

5. "SNAP I Power Conversion System Alternator Development," ER-4052, TRW, 20 June 1960.

6. "SNAP I Power Conversion System Pump Development," ER-4053, TRW, 20 June 1960.

7. "SNAP I Power Conversion System Bearing Development," ER-4054, TRW, 20 June 1960.

8. "SNAP I Power Conversion System Control Development," ER-4055, TRW, 20 June 1960.

9. "SNAP I Power Conversion System Condenser-Radiator Development," ER-4056, TRW, 20 June 1960.

10. "SNAP I Power Conversion System Materials Development," ER-4057, TRW, 20 June 1960. 